\title{
COTAS SEM DIREITO DE VOTO NA SOCIEDADE LIMITADA: PANORAMA BRASILEIRO E NORTE-AMERICANO
}

\section{NONVOTING MEMBERSHIP INTERESTS IN LIMITED LIABILITY COMPANY (LLC): AN OVERVIEW OF THE BRAZILIAN AND USA LEGAL SYSTEMS}

\author{
LeONARdo NetTo Parentoni \\ Doutor em Direito pela Universidade de São Paulo (USP). Procurador Federal de Categoria Especial/AGU. \\ Professor Adjunto de Direito Empresarial da Faculdade de Direito da Universidade Federal de Minas Gerais (UFMG) e \\ do Instituto Brasileiro de Mercado e Capitais (IBMEC/MG). \\ parentoni@gmail.com \\ JACQUELINE DeLGado MIRANDA \\ Bacharelanda em Direito pela Universidade Federal de Minas Gerais. \\ Bolsista de iniciação científica pela Universidade Federal de Minas Gerais (UFMG).
} jacquelinedelgadomiranda@hotmail.com

\section{RESUMO}

A sociedade limitada é o tipo societário mais comum no Brasil e nos Estados Unidos vem ganhando espaço. Nela a possibilidade de restrição do direito de voto é tema controverso. O objetivo do presente artigo é analisar a admissibilidade das participações societárias preferenciais, numa análise comparativa entre os sistemas jurídicos brasileiro e norte-americano. A metodologia utilizada consiste no levantamento da base bibliográfica nos dois sistemas jurídicos. Discutese que, no Brasil, o CC/02, art.1.055, caput, dispõe sobre o tema de forma simples e genérica, contudo, nos quoruns previstos, não permite cotas preferenciais sem direito de voto. Além disso, o DNRC (Departamento Nacional de Registro do Comércio) manifestou-se pelo não cabimento para sociedade limitada da figura da quota preferencial. A doutrina, por sua vez, divide-se a este respeito. Conclui-se que há um equívoco dos órgãos de registro empresarial do país, por outro lado, a proibição é justificável e admissível. Já nos EUA, a existência de cotas preferenciais é um assunto puramente contratual.

Palavras-chave:cotas preferenciais sem direito de voto; Direito Societário; sociedade limitada.

\begin{abstract}
The limited liability company is the most common society type on Brazil and it is gaining force on the United States. The possibility of vote restriction is a controversal theme within it. The goal of the present article is to analyze the admissibility of the preferential corporate participation, on a comparative analysis between the law systems of Brazil and USA. The method used consists on building a bibliographical reference base of both systems. It is argued that, in Brazil, the CC/02, art.1.055, caput, discuss about the theme on a simple and generic way, however, on the previewed quoruns, it doesn't allow the use of preferential quotas with no rights to vote. Not only that, the DNRC manifested for the inviability of the preferential quotas for the limited liability company. The doctrine, on the other side, splits itself in regards to this. The conclusion is that there is a problem on the business register departments of the country. On the other hand, the prohibition is justifiable and permissible. On the USA, the existance of preferential quotas is a purely contractual matter.
\end{abstract}

Keywords: nonvoting membership interests; Corporate Law; limited liability company - LLC. 


\section{SUMÁRIO}

INTRODUÇAO; 1 BREVÍSSIMO HISTÓRICO DAS SOCIEDADES LIMITADAS; 1.1 Sociedade Limitada no Brasil; 1.2 Sociedade Limitada nos EUA. 2 COTAS SEM DIREITO DE VOTO NO BRASIL; 2.1 Participações Societárias Preferenciais: Conceito; 2.2 Vantagens e desvantagens das participações societárias preferenciais com restrição de voto; 2.3 Ações preferenciais com restrição de voto, na legislação; 2.4 Cotas preferenciais com restrição de voto, na legislação; 2.5 Posicionamento do DNRC e do DREl; 2.6 Posição dos Autores;3COTAS SEM DIREITO DE VOTO NOS EUA;CONCLUSÃO; REFERÊNCIAS.

\section{INTRODUÇÃO}

Este texto tem por objetivo analisar as cotas sem direito de voto na sociedade limitada brasileira, fazendo um paralelo com o tratamento dispensado ao tema pelo Direito Societário ${ }^{1}$ norte-americano, no que se refere às sociedades de mesmo tipo, lá denominadas limited liability company - LLC.

Tal abordagem focará somente nos aspectos de Direito Comercial. ${ }^{2}$ Demais facetas da questão, como as implicações para o Direito Tributário ou Processual Civil, propositadamente, não serão objeto de análise.

Ademais, este estudo contempla apenas a supressão do direito de voto decorrente de previsão no próprio contrato social, deixando de lado as restrições porventura ajustadas em instrumentos separados, como os acordos de cotistas, a utilização de holdings ou os fundos de investimento.

\footnotetext{
${ }^{1}$ Ainda que a generalidade dos manuais brasileiros - surpreendentemente - não conceitue Direito Societário, pode-se entendê-lo como o sub-ramo do Direito Comercial que estuda a constituição, o funcionamento e a extinção das sociedades, notadamente das sociedades empresárias. Equivale ao Corporate Law, nos países de Common Law; ao Diritto Societario, na Itália; ao Derecho Societario, em países de língua hispânica; ou ao Direito das Sociedades, em Portugal.

Há quem adote visão mais ampla de Direito Societário, englobando também as associações: ADAMEK, Marcelo Vieira von. Abuso de Minoria em Direito Societário. São Paulo: Malheiros, 2014. p. 37. "O direito societário é o direito das organizações finalísticas privadas e o seu estudo compreende as associações em sentido estrito e as sociedades - as quais daquelas se distinguem pelo seu escopo-fim lucrativo, mas que, em qualquer caso, também têm por substrato pessoal a reunião de pessoas (...)."

Outros, por sua vez, adotam visão diversa, associando Direito Societário e conflito de interesses: HANSMANN, Henry; DAVIES, Paul; KRAAKMAN, Reinier R. et al. The Anatomy of Corporate Law: A Comparative and Functional Approach. Oxford: Oxford University Press, 2004.

A visão dos autores deste texto, portanto, insere-se numa via intermediária, que se reputa mais correta.

${ }^{2}$ FORGIONI, Paula Andrea. A Evolução do Direito Comercial Brasileiro: da mercancia ao mercado. São Paulo: Revista dos Tribunais, 2009. p. 18. "O objeto do direito mercantil não é toda a ordem jurídica do mercado, mas apenas aquela que tem a ver com a organização da empresa e com a interação entre empresas."
} 
O texto se divide em 04 (quatro) partes, algumas das quais contam com subtópicos. A Parte I destina-se à introdução e ao esclarecimento dos cortes metodológicos utilizados na pesquisa. A Parte II trata dos modelos brasileiro e norte-americano de sociedade limitada, enfocando brevemente a sua evolução histórica, desde a primeira previsão legislativa até a configuração que apresentam nos dias de hoje. Na sequência, a Parte III cuida especificamente das cotas sem direito de voto no Brasil, explicando no que consistem, suas vantagens e desvantagens, além das previsões legais a respeito e do posicionamento dos órgãos de registro empresarial. Esta parte se encerra trazendo o posicionamento pessoal dos autores acerca da impossibilidade de adoção das cotas preferenciais sem direito de voto no Brasil, à luz da legislação em vigor. Após, a Parte IV descreve o funcionamento das cotas sem direito de voto nos EUA, onde esta prática é amplamente aceita, ressaltando as diferenças no trato da mesma matéria entre os dois Estados. Por fim, segue a conclusão do trabalho, no sentido de ter sido infeliz a opção brasileira por terminantemente proibir as cotas sem direito de voto.

Esclarecidos estes cortes metodológicos, bem como a estrutura do texto, passa-se à análise do tema.

Com efeito, a sociedade limitada é, em termos quantitativos, o tipo societário mais abundante no Brasil. ${ }^{3}$ Trata-se também, como se verá adiante, de criação praticamente centenária, em relação à qual já foram construídas sólida doutrina e jurisprudência. Este tipo societário tem como uma de suas principais vantagens a maleabilidade ${ }^{4}$, capaz de viabilizar sua adoção para empreendimentos de diversos portes, desde pequenas empresas até multinacionais.

${ }^{3}$ Conforme estatísticas do antigo Departamento Nacional de Registro do Comércio - DNRC, colhidas até o ano de 2005 , as sociedades limitadas representavam mais de $90 \%$ dos tipos societários registrados no país, excluindo-se as cooperativas: BRASIL. Departamento Nacional de Registro do Comércio - DNRC. Estatísticas. Brasília: DNRC. Disponível em <http://www.dnrc.gov.br/>. Acesso em 28 nov. 2015.

No mesmo sentido: TOMAZZETE, Marlon. Curso de Direito Empresarial:Teoria Geral e Direito Societário. 5. ed. São Paulo: Atlas, 2013. v. 1, p. 342. "No Brasil, as sociedades limitadas representam $98,93 \%$ das sociedades constituídas no período de 1985 a 2005 . No ano de 2005 , elas representaram $98,53 \%$ de todas as sociedades constituídas."

Lamentavelmente, o atual órgão de registro, o Departamento de Registro Empresarial e Integração - DREI, não disponibiliza estatísticas discriminadas por tipo societário. Vide: BRASIL. Departamento de Registro Empresarial e Integração - DREI. Estatísticas. Brasília: DREI. Disponível em <http://drei.smpe.gov.br//assuntos/estatisticas/capa-editoria-b>. Acesso em 28 nov. 2015.

Assim, fica difícil trazer dados precisos sobre o percentual de sociedades limitadas atualmente registradas, em comparação aos demais tipos de sociedade pluripessoal. A vivência prática, no entanto, sugere que continuam sendo esmagadora maioria.

${ }^{4}$ CORDEIRO, António Menezes. Direito das Sociedades Das Sociedades em Geral. 2. ed. Coimbra: Almedina, 2014. v. II, p. 229. "Podemos, sem exagero, considerar que, mercê de vários factores incluindo alguns de natureza psicológica - as sociedades por quotas traduzem um tipo de organização capaz de desenvolver qualquer espécie de actuação humana lícita." 
Diversamente, o tipo societário correspondente nos EUA, denominado limited liability company - LLC, foi introduzido em época muito mais recente e ainda desperta diversos questionamentos, tanto na doutrina quanto na jurisprudência. Curiosamente, questões sobre sociedade limitada, há bastante tempo pacificadas no Brasil, até recentemente ainda eram objeto de discussão nos EUA. ${ }^{5}$ Não obstante, a LLC vem ganhando espaço e sendo cada vez mais utilizada naquele país, a ponto de ter se tornado a principal opção para empreendimentos de pequeno porte.

Portanto, entende-se que uma análise comparativa entre essas duas experiências pode se revelar frutífera e esclarecedora. É o que se buscará desenvolver nos tópicos seguintes, principiando pela breve linha evolutiva histórica da sociedade limitada nesses dois países.

\section{BREVÍSSIMO HISTÓRICO DAS SOCIEDADES LIMITADAS}

\subsection{Sociedade Limitada no Brasil}

O Código Comercial Brasileiro de 1850 não tratou das sociedades limitadas ${ }^{6}$, até porque a sua criação somente viria a ocorrer posteriormente, em 1892, na Alemanha. ${ }^{7}$

\footnotetext{
5Vide, por exemplo, em relação ao enquadramento da LLC como sociedade "de pessoas" ou "de capitais", as seguintes opiniões díspares da doutrina: RIBSTEIN, Larry E. An Analysis of the Revised Uniform Limited Liability Company Act. Virginia Law \& Business Review. Charlottesville: University of Virginia. v. 03, n. 01, p. 36-80, Spring. 2008, p. 54. "LLC statutes provide rules for admitting new members and for transferring membership interests. In both cases, the default rules reflect the traditional partnership approach of permitting members to choose their colleagues."

Em sentido oposto: HANSMANN, Henry; KRAAKMAN, Reinier; SQUIRE, Richard. The New Business Entities in Evolutionary Perspective. University of Illinois Law Review. Urbana-Champaign: University of Illinois College of Law. v. 05, n. 01, p. 05-14, Feb. 2005, p. 06. "The new forms are thus better understood as part of the continuing development of the corporate form rather than as entities more akin to the traditional partnership which has, in fact, been evolving in a different direction."

${ }^{6}$ FERREIRA, Waldemar Martins. Sociedades por Quotas. 5. ed. São Paulo: Monteiro Lobato, 1925, p. 01. "O Código de Commércio não disciplinou as sociedades de responsabilidade limitada, ou por quotas. Nem as leis posteriores, ainda mesmo o Decreto n. 434, de 4 de julho de 1891, que consolidou as disposições legislativas e regulamentares sobre as sociedades anonymas, a ellas se referiram."

7 Houve, durante algum tempo, discussão doutrinária a respeito do pioneirismo na instituição de sociedades limitadas, se pertencente à Alemanha ou à Inglaterra:REQUIÃO, Rubens. Curso de Direito Comercial. 25. Ed/. São Paulo: Saraiva, 2003. v. 1, p. 456. "O surgimento das sociedades por cotas de responsabilidade limitada está envolto em viva controvérsia. Uns consideram-na de origem britânica e outros, alemã. Deve-se essa divergência ao uso que a legislação inglesa fez da expressão limited, secundada pela legislação francesa de 1863, que instituiu uma sociedade anônima impropriamente denominada de société à responsabilité limitée."

Hoje, porém, é incontroverso o pioneirismo alemão no trato do tema. Vide, por exemplo: LOBO, Jorge. Sociedades Limitadas. Rio de Janeiro: Forense, 2004. v. 1, p. 48. "O 'Projeto de lei, relativo às
} 
COTAS SEM DIREITO DE VOTO NA SOCIEDADE LIMITADA: PANORAMA BRASILEIRO E NORTE-AMERICANO

Leonardo NetTo Parentoni JACQUELINE DELGADO MIRANDA

Já no início do século XX, após a criação da sociedade limitada na Alemanha e sua difusão para outros países europeus, coube a Inglês de Souza realizar os primeiros estudos legislativos sobre o tema, no Brasil, por ocasião de um Projeto de Reforma do Código Comercial de 1850. Este estudo serviu de base a projeto apresentado pelo então Deputado Joaquim Luís Osório que, em 10 de janeiro de 1919, viria a se tornar a primeira legislação pátria sobre o assunto, o Decreto n. 3.708/1919. ${ }^{8}$

Contendo apenas 19 (dezenove) artigos, esse decreto primava pela concisão. De início, a norma fora duramente criticada, sob o argumento de que não seria o bastante para regular, de modo satisfatório, o novo tipo societário. ${ }^{9} 0$ passar dos anos, porém, veio a demonstrar justamente o contrário. A concisão do Decreto n. 3.708/1919 permitiu que sobre ele fossem sendo construídas, paulatinamente, riquíssimas doutrina e jurisprudência. Esta concisão legislativa, antes acoimada de defeito, revelou-se, em verdade, uma virtude. ${ }^{10}$ Tal aspecto, aliado ao trabalho de constante atualização interpretativa, fez com que o Decreto n. 3.708/1919 se tornasse uma das mais longevas legislações comerciais do país, perdurando por mais de 80 (oitenta) anos, sem nunca ter sofrido qualquer modificação em seu texto original. Esta lei

sociedades de responsabilidade limitada', publicado pelo Departamento de Justiça do Reich em dezembro de 1891, revisto pelo Senado em fevereiro de 1892, concebia a sociedade limitada como uma sociedade anônima de pequeno porte, uma forma intermediária entre as sociedades personalistas e as de capitais."

${ }^{8}$ BRASIL. Congresso Nacional. Decreto $\mathrm{n}^{\circ} 3.719$ de 15 de janeiro de 1919 . Corrige enganos com que foi publicada a lei n. 3.674, de 7 de janeiro de 1919. In: Diário Oficial da União. Rio de Janeiro, RJ. "Art. $1^{\circ}$. Além das sociedades a que se referem os arts. 295, 311, 315 e 317 do Código Commercial, poderão constituir-se sociedades por quotas, de responsabilidade limitada."

${ }^{9}$ FERREIRA, Waldemar Martins. Sociedades por Quotas. 5. ed. São Paulo: Monteiro Lobato, 1925, p. 131132. "Já vimos que o Decreto n. 3.708 é de uma defficiência, de uma mudez simplesmente pasmosa. Não lhe bastou deixar em branco os mais sérios problemas que se podem agitar na organização e constituição da sociedade de responsabilidade limitada. Esqueceu-se de que, limitando a responsabilidade dos sócios, pelas obrigações contraídas pelas sociedades, ao montante do capital social, erigiu um regímen de excepção, que devia ser cuidadosamente regulado, ponto a ponto, afim de evitar a fraude.

Preferiu deixar a sua missão de estabelecer, em suas linhas geraes, a ossatura de um novo typo de sociedades mercantis, ao capricho das partes contractantes. Contentou-se, e contentou-se com muito pouco, em dizer, no seu art. 18, que 'serão observadas quanto às sociedades por quotas, de responsabilidade limitada, no que não fôr regulado no estatuto social, e na parte applicável, as disposições das leis das sociedades anonymas."

${ }^{10}$ BORGES, João Eunápio. Curso de Direito Comercial Terrestre. Rio de Janeiro: Forense, 1959. v. 1, p. 67. "Em 1919, pelo Dec. n. ${ }^{\circ} 3.708$, de 10 de janeiro, foi introduzido em nossa legislação novo tipo de sociedade por cotas, de responsabilidade limitada, que, de mais simples organização e funcionamento do que as sociedades anônimas, veio permitir a todos os sócios, inclusive gerentes ou diretores, o exercício do comércio sem os riscos decorrentes da responsabilidade solidária e ilimitada pelas dívidas sociais."

No mesmo sentido: BORBA, José Edwaldo Tavares. Direito Societário. 9. ed. Rio de Janeiro: Renovar, 2004, p. 74. "Caracteriza-se ainda a sociedade por cotas pela flexibilidade existente na sua formulação. Sendo o Decreto $\mathrm{n}^{\circ} 3.708 / 19$ extremamente sumário - tem apenas dezenove artigos - poucas são as normas imperativas. Cabe, assim, aos sócios e seus advogados uma ampla liberdade no estabelecimento das cláusulas e condições que deverão reger a sociedade." 
acompanhou, com sucesso, a própria evolução do capitalismo brasileiro, desde a economia baseada na produção agrícola, em regime familiar, até o êxodo rural, a mecanização e o desenvolvimento da indústria, culminando com a globalização do final do século XX.

O primado do Decreto n. 3.708/1919 somente viria a terminar com a entrada em vigor do atual Código Civil, em 10 de janeiro de 2003. Contrariando toda a lógica da legislação anterior - que, repita-se, já provara ter sido bem-sucedida -, o Código Civil optou por conferir à sociedade limitada tratamento muito mais complexo e detalhado, impondo-lhe deveres e custos antes inexistentes. Por exemplo, ao tratar de certos órgãos societários, anteriormente restritos às sociedades por ações, como o Conselho Fiscal.

Talvez o ponto de maior retrocesso do atual Código Civil esteja relacionado aos artigos 1.071 e 1.076, que preveem um emaranhado de quóruns obrigatórios, para os mais diversos assuntos, capazes de causar confusão até mesmo nos profissionais do Direito. Imagine-se, então, nas sociedades de pequeno porte, totalmente desprovidas de assessoria jurídica. Lembrando que, neste assunto, o Decreto n. 3.708/1919 possibilitava, como regra, que todas as deliberações sociais fossem tomadas por maioria de votos. Competiria a cada sociedade, por meio de previsão contratual específica, instituir quóruns especiais, mais elevados, segundo as suas necessidades específicas. Isto permitia, a um só tempo, a existência de regra simples e intuitiva, aplicável à generalidade das limitadas, sem com isto excluir a possibilidade de estruturação de quóruns complexos, apenas para as sociedades que deles efetivamente necessitassem, normalmente as de maior porte econômico. Ao invés de prosseguir nessa linha, o Código Civil de 2002 optou por burocratizar o tema, convertendo em padrão a estrutura complexa e intricada, tornando-a obrigatória para todas as sociedades limitadas. Por óbvio, este retrocesso não escapou de críticas da doutrina. ${ }^{11}$

\footnotetext{
${ }^{11}$ DINIZ, Gustavo Saad. A primeira década do Código Civil e alguns problemas para as organizações empresariais. Revista dos Tribunais. São Paulo: Revista dos Tribunais, v. 101, n. 917, p. 207-222, mar. 2012, p. 215. "Não é demais ressaltar que o texto do Código Civil de 2002 vem recebendo imensas críticas pela nova disciplina das sociedades limitadas, aproximando-as das sociedades simples. Somente para ficar num dos exemplos, basta verificar que o Código Civil de 2002 rompeu com a consolidação do princípio da maioria do capital social para os quóruns gerais de deliberação, assentando uma confusa pauta de diversos volumes de capital, dispersos assistematicamente nos arts. 1.061, 1.063, § 1. , e 1.076 do CC/2002." Igualmente: BORBA, José Edwaldo Tavares. Direito Societário. 9. ed. Rio de Janeiro: Renovar, 2004, p. 100. "Hoje, quando muitos países adotam uma sociedade anônima simplificada, a fim de flexibilizar os pequenos e médios negócios, o novo Código Civil complica e burocratiza um modelo societário consagrado pela prática."
} 
Hoje, portanto, a sociedade limitada brasileira conta com regramento minucioso, aplicando-se, subsidiariamente, as regras da sociedade simples ou da sociedade anônima, conforme o caso. ${ }^{12}$

Sabe-se, ainda, que estão em tramitação no Congresso Nacional dois Projetos de Novo Código Comercial ${ }^{13}$, fruto da iniciativa de Fábio Ulhoa Coelho. ${ }^{14}$ Neles, pretende-se resgatar o modelo histórico da sociedade limitada que vinha dando certo na vigência do Decreto $n$. 3.708/1919 (baseado na concisão e simplicidade) ${ }^{15}$, acrescido de alguns aprimoramentos, como a previsão da sociedade limitada unipessoal.

Este, em suma, é o brevíssimo histórico da sociedade limitada no Brasil. Passa-se, agora, ao histórico do tema nos Estados Unidos da América.

\subsection{Sociedade Limitada nos EUA}

Durante séculos, as general partnerships ${ }^{16}$, ao lado das sociedades por ações (corporations), foram os tipos societários dominantes nos Estados Unidos da América, sendo as

\footnotetext{
${ }^{12}$ BRASIL. Congresso Nacional. Código Civil. Brasília: 10 jan. 2002. "Art. 1.053. A sociedade limitada regese, nas omissões deste Capítulo, pelas normas da sociedade simples.

Parágrafo único. 0 contrato social poderá prever a regência supletiva da sociedade limitada pelas normas da sociedade anônima."

13 Um deles no Senado e outro na Câmara dos Deputados. Respectivamente: BRASIL. Senado Federal. Projeto de Lei n. 487. Autor: Senador Renan Calheiros. Brasília: 22 nov. 2013; e BRASIL. Câmara dos Deputados. Projeto de Lei n 1.572. Autor: Deputado Vicente Cândido. Brasília: 14 jun. 2011.

${ }^{14}$ Ideia publicada na seguinte obra: COELHO, Fábio Ulhoa. O Futuro do Direito Comercial. São Paulo:

Saraiva, 2011.

${ }^{15}$ BRASIL. Senado Federal. Projeto de Lei n. 487. Autor: Senador Renan Calheiros. Brasília: 22 nov. 2013. Exposição de Motivos da Comissão de Juristas: "[Constitui objetivo do novo Código Comercial]: (iv) simplificação e desburocratização da vida empresarial, com a eliminação de exigências anacrônicas ou despropositadas, de que são exemplos a revisão das regras sobre sociedades limitadas (...)."

${ }^{16}$ KLEIN, William A.; COFFEE, John C.; PARTNOY JR, Frank. Business Organization and Finance: Legal and Economic Principles. 11. ed. New York: Foundation Press, 2010, p. 63. "Where two people own real estate as joint tenants, they share in profits and are co-owners, but they are not partners unless the management of the property requires enough activity to constitute a 'business'. Where people are engaged in a business, however, they are partners if they share in profits and control. That is the very brief, very rough, imprecise rule-of-thumb definition of partnerships.
}

(...)

Despite the consensual nature of the relationship, however, the failure of the associates to label themselves 'partners', or to think of themselves as belonging to a partnership, is irrelevant. If they share in the profits and in the control of a business they are partners as a matter of law and are subject to the rights and liabilities that flow from that status, like it or not."

As general partnerships, nos EUA, desempenham dúplice função: 1) consistem no regime jurídico aplicável a quem exerce de fato a empresa, por meio da associação entre duas ou mais pessoas físicas, porém sem realizar os registros legalmente exigidos (semelhante à sociedade em comum); e 2) tipo societário das 
primeiras utilizadas para empreendimentos de menor porte econômico ${ }^{17}$, enquanto estas últimas se voltavam a iniciativas de médio ou grande porte. ${ }^{18} \mathrm{~A}$ quase totalidade dos empreendimentos optava por um ou outro desses tipos. Não existia, naquele país, uma via intermediária, capaz de conjugar a limitação de responsabilidade patrimonial dos sócios (típica das sociedades por ações) com o baixo custo de constituição e administração das partnerships. Tal lacuna somente viria a ser preenchida ao final da década de 70, com a introdução das sociedades limitadas.

Isso se deu da seguinte forma. Na década de 50, após a II Guerra Mundial, vários países europeus enfrentavam grave crise econômica. Seguindo o protagonismo da Alemanha, decidiram, então, introduzir o tipo da sociedade limitada, como forma de estímulo ao mercado, justamente por conjugar as duas vantagens anteriormente mencionadas (limitação de responsabilidade dos sócios e estrutura simplificada de funcionamento). Paralelamente, nessa mesma época, as grandes companhias abertas norte-americanas ampliavam, cada vez mais, sua participação no comércio internacional, principalmente com as nações europeias. Ao constituírem suas controladas nos países europeus, as companhias americanas, em muitos casos, utilizaram-se das sociedades limitadas. Tanto que a Internal Revenue Service ${ }^{19}$ se viu obrigada a editar as primeiras normas infralegais regulamentando a tributação de lucros provenientes de sociedades limitadas estrangeiras ${ }^{20}$. Já nessa época, a sociedade limitada era conhecida pelos norteamericanos, porém ainda não tipificada em lei. Curiosamente, esta lei viria a ser fruto de intenso lobby.

Com efeito, a Hamilton Brothers Oil, companhia norte-americana constituída na cidade de Denver, Colorado, desde os anos 60 mantinha negociações com países da América Latina, nos

atividades registradas, nas quais o voto dos sócios costuma ser per capta, os poderes de administração são concedidos a todos os sócios e a responsabilidade deles, pelas dívidas sociais, é ilimitada (semelhante à sociedade em nome coletivo).

${ }^{17}$ KLEIN, William A.; COFFEE, John C.; PARTNOY JR, Frank. Business Organization and Finance: Legal and Economic Principles. 11. ed. New York: Foundation Press, 2010, p. 52. “(...) partnerships are encountered most frequently in those sectors of the economy (...) where optimal firm size is relatively small. (...) Partnership law is addressed primarily to the firm with a few partners, all of whom are involved in the operation of the business (...)."

${ }^{18}$ ROE, Mark J. Strong Managers, Weak Owners: The Political Roots of American Corporate Finance. Princeton: Princeton University Press, 1994, p. 03. "The public corporation (...) is the dominant form of enterprise in the United States. Why? Technology dictated large enterprises as an engineering matter. The large throughput technologies that developed at the end of the nineteenth century (...) mean that cheaper production accrued to the firm with the largest scale."

${ }^{19}$ Equivalente à Receita Federal do Brasil.

20 BAGLEY, William D.; WHYNOTT, Philip P. The Limited Liability Company. Los Angeles: James Publishing, 1994. "By 1956, the IRS had begun issuing classification private letter rulings for foreign LLCs that were subject to the U.S. tax code. In fact, the IRS issued over 130 private letter rulings involving LLCs from 1956 until enactment of the first American LLC Act in Wyoming". 
COTAS SEM DIREITO DE VOTO NA SOCIEDADE LIMITADA: PANORAMA BRASILEIRO E NORTE-AMERICANO

Leonardo NetTo Parentoni JACQUELINE DELGADO MIRANDA

setores de óleo e gás, por meio de suas controladas, registradas nesses países como sociedades limitadas. Desejando utilizar-se do mesmo modelo no mercado interno, a Hamilton Brothers Oil encomendou a um grupo de advogados estudo sobre a possibilidade de se adotar a sociedade limitada também nos Estados Unidos da América.

De posse desse estudo, faltava exercer lobby político suficiente para que ele fosse convertido em lei. Então, a companhia escolheu como alvo o Estado-membro do Aalaska, por ser um dos menos povoados e com menor representatividade política do país, o que, a seu ver, facilitaria a aprovação do projeto. ${ }^{21}$ Surpreendentemente, porém, o Alaska rejeitou a proposta, em 1976 22 . Diante desta recusa, a Hamilton Brothers Oil apresentou a mesma proposta ao Estado-membro de Wyoming, no ano seguinte. Em pouco tempo ela foi integralmente aceita, sem qualquer alteração no texto ${ }^{23}$, convertendo-se, em 30 de junho de 1977, na primeira lei norte-americana sobre sociedades limitadas, conhecida como Wyoming LLC Act, de $1977 .{ }^{24}$

Ocorre que, mesmo vencida a barreira legislativa, com a introdução do novo tipo societário, a sociedade limitada ainda não havia deslanchado nos EUA. Isto porque havia fundada dúvida se ela seria tributada como partnership (mais vantajoso para o empreendedor) ou como S/A (em tese, mais caro). Somente em 1988, com o Revenue Ruling $88 / 76^{25}$, esta questão

${ }^{21}$ Lembrando que a competência legislativa em Direito Societários, nos EUA, é de regra estadual, ao
contrário do Brasil, em que sempre imperou a competência privativa da União. Vide: ROMANO, Roberta.
The Genius of American Corporate Law. Washington: AEI Press, 1993. Também o nosso texto, no prelo: PARENTONI, Leonardo; GONTIJO, Bruno Miranda. Competência Legislativa em Direito Societário: Sistemas Brasileiro, Norte-Americano e Comunitário Europeu.

22 HAMILL, Susan Pace. The Origins Behind the Limited Liability Company. Ohio State Law Journal. Columbus: Ohio State University, v. 59, n. 05, p. 1459-1522, mar. 1998, p. 1464-1465. "The newly created LLC, presented to the Alaska legislature on April 8, 1975, offered for the first time the potential for a domestic entity to combine the tax advantages of a partnership with direct limited liability commonly associated with corporations. The sponsors understood that the Alaska bill posed a major breakthrough for U.S. business organizations and would likely be scrutinized as very tax- sensitive. After much debate and effort and two attempts, once in April of 1975 and once in April of 1976, the Alaska bills died, apparently for political reasons unrelated to the proposals."

${ }_{23}$ BAGLEY, William D.; WHYNOTT, Philip P. The Limited Liability Company. Los Angeles: James Publishing, 1994. "Nothing, not even a comma, in the proposed LLC legislation drafted by Hamilton Brothers was changed by the Wyoming Legislature. Promptly signed by Governor Herschler, the act became effective June 30, 1977."

${ }^{24}$ Op. cit. "So, Hamilton Brothers decided to create their own LLC act and have it passed, choosing Wyoming as the state to seek enactment. (...) Introduced in the Wyoming Senate by Senator Neil Stafford as Senate File 218, the LLC legislation permitted the creation of a new business entity (...)."

RUTLEDGE, Thomas E. Let's Stop Describing LLCs as "Hybrids". Journal of Passthrough Entities. New York: CCH Incorporated. v. 33, n. 01, p. 33-38, Sep./Oct. 2014, p. 34. “(...) LLCs are entire strangers to the common law; there was no LLC before there was an LLC Act."

${ }^{25}$ HAMILL, Susan Pace. The Origins Behind the Limited Liability Company. Ohio State Law Journal. Columbus: Ohio State University, v. 59, n. 05, p. 1459-1522, mar. 1998, p. 1470. "After the IRS's landmark decision to recognize the LLC's right to be taxed under the partnership provisions, the states slowly and 
tributária restou finalmente resolvida, permitindo-se à LLC optar entre o tratamento tributário da corporation ou o da partnership (sistema conhecido como check the box). Daí por diante a sociedade limitada caiu no gosto dos norte-americanos - e também dos empreendedores estrangeiros que fazem negócios nesse país -, tendo se tornado o principal tipo societário para empreendimentos de pequeno porte ${ }^{26}$, à semelhança do que ocorre no Brasil. Tanto que, nas últimas décadas, o número de LLC's $^{27}$ constituídas para abrigar empreendimentos de menor porte tem sido aproximadamente três vezes maior do que o de sociedades anônimas. ${ }^{28}$ Atualmente, todos os Estados-membros norte-americanos possuem legislação a respeito da LLC, sendo que o Havaí foi o último a editá-la, em $1997 .^{29}$

Não é o escopo deste texto adentrar o federalismo norte-americano, explicando como se distribuem as competências legislativas naquele país ${ }^{30}$. Basta mencionar que os Estadosmembros dos EUA editam leis sobre Direito Societário, a fim de atrair a constituição e o registro do maior número possível de sociedades em seu território, para lucrar com a cobrança das respectivas taxas. A sociedade registrada num determinado Estado-membro fica submetida à legislação deste e às normas federais, mas pode exercer suas atividades em todo o território nacional. E, sem dúvida, Delaware é o Estado-membro mais bem-sucedido. Estima-se que $60 \%$ das companhias abertas estejam registradas nele, além de expressivo número de LLC's.

cautiously started to enact legislation allowing for the formation of LLCs. It took until 1990-the year Colorado and Kansas both passed LLC statutes-for any states to step forward and recognize the creation of LLCs in light of the IRS's revenue ruling."

${ }^{26}$ KLEIN, William A.; COFFEE, John C.; PARTNOY JR, Frank. Business Organization and Finance: Legal and Economic Principles. 11. ed. New York: Foundation Press, 2010, p. 51. "In recent years, the Limited Liability Company (LLC) has become the dominant form of legal organization for small business."

${ }^{27}$ Vide, por todos: KOBAYASHI, Bruce H.; RIBSTEIN, Larry E. Delaware for Small Fry: Jurisdictional Competition for Limited Liability Companies. University of Illinois Law Review. Urbana-Champaign: University of Illinois College of Law. v. 2011, n. 01, p. 91-144, 2011.

${ }^{28}$ CONAWAY, Ann E. A Business Review of the Delaware Series: Good Business for the Informed. Widener Law School Research Paper Series.Wilmington: Widener Law School, n. 19, p. 01-58, Oct. 2008. Disponível em: <http://papers.ssrn.com/sol3/papers.cfm?abstract_id=1097645>. Acesso em 02 dez. 2015, p. 03. "In 2006, 96,831 new LLCs were formed in Delaware compared with 34,733 new corporations." Igualmente: WALKER, David S. A Consideration of an LLC for a 501(C)(3) Nonprofit Organization. Drake University Law School Research Paper Series. Des Moines: Drake University, n. 24, p. 626-677, Oct. 2012. Disponível em: <http://papers.ssrn.com/sol3/papers.cfm?abstract_id=2158907>. Acesso em $02 \mathrm{dez}$. 2015, p. 634. "In contrast to the corporation, in the business world the limited liability company, or LLC, has become the predominant choice of form in which to organize a business, and many more LLCs are being formed today than corporations."

${ }_{29}$ UNITED STATES OF AMERICA. Limited Liability Company Center. Disponível em: <http://www.limitedliabilitycompanycenter.com/>. Acesso em: 02 dez. 2015.

${ }^{30}$ Pra isto, recomenda-se: PARENTONI, Leonardo; GONTIJO, Bruno Miranda. Competência Legislativa em Direito Societário: Sistemas Brasileiro, Norte-Americano e Comunitário Europeu. No prelo. 
Consequentemente, para o estudo das cotas sem direito de voto (nonvoting membership interests) será utilizada apenas a lei de Delaware. ${ }^{31}$

Por fim, vale frisar que nos EUA existe, ainda, a tendência de editar propostas elaboradas por grupos de juristas, denominadas de “Leis Uniformes” (uniform law) ${ }^{32}$, a fim de harmonizar as diversas legislações estaduais. Tais propostas não configuram lei em sentido estrito e, portanto, não são vinculantes. Sua intenção é a de padronizar nacionalmente o funcionamento de determinados assuntos, reduzindo assimetrias e custos de transação. Para tanto, espera-se que Estados-membros adotem em sua legislação interna, voluntariamente, prescrições idênticas ou ao menos similares às da "Lei Uniforme". Sua redação é bastante curiosa para os padrões brasileiros. Com efeito, após cada grupo de artigos pertinente a determinado assunto costuma vir um esclarecimento doutrinário (proveniente da Comissão que elaborou o texto), sugerindo a melhor interpretação dos dispositivos, seguida de alguns exemplos práticos.

Certas leis uniformes em matéria de Direito Societário obtiveram grande êxito, tendo sido internalizadas por quase todos os Estados-membros, ainda que com ressalvas num ou noutro ponto $^{33}$. Porém, as leis uniformes sobre sociedade limitada, conhecidas como ULLCA (Uniform Limited Liability Company Act, de 1995) e RULLCA (Revised Uniform Limited Liability Company Act - RULLCA, de 2006, revisado em 2013), são pouco utilizadas, porque terem sofrido pesadas críticas $^{34}$. Apesar disto considera-se útil abordá-las, o que será feito adiante.

\section{COTAS SEM DIREITO DE VOTO NO BRASIL}

\subsection{Participações Societárias Preferenciais: Conceito}

31 UNITED STATES OF AMERICA. Delaware Department of State. Delaware Limited Liability Company Act.Disponível em: <http://delcode.delaware.gov/title6/c018/>. Acesso em: 02 dez. 2015. "§ 18-101 Definitions. As used in this chapter unless the context otherwise requires:

(...) (8) 'Limited liability company interest' means a member's share of the profits and losses of a limited liability company and a member's right to receive distributions of the limited liability company's assets."

${ }^{32}$ UNITED STATES OF AMERICA. Uniform Law Commission. Disponivel em: <http://www.uniformlaws.org/>. Acesso em: 20 abr. 2015.

${ }^{33}$ Ao tempo em que redigido este texto, Lousiana era o único Estado-membro que não havia aderido à lei uniforme em matéria de partnerships, por exemplo.

${ }^{34}$ RIBSTEIN, Larry E. An Analysis of the Revised Uniform Limited Liability Company Act. Virginia Law \& Business Review. Charlottesville: University of Virginia. v. 03, n. 01, p. 36-80, Spring. 2008, p. 79-80. 
Participações societárias preferenciais ${ }^{35}$ são aquelas que atribuem a seus titulares direitos e deveres diversos daqueles conferidos pelas participações ordinárias. Em troca de alguma vantagem, impõem também certas restrições. A principal delas costuma ser a restrição ou mesmo a supressão do direito de voto. ${ }^{36}$ Esse tipo de participação societária é muito comum nas sociedades anônimas, onde se denominam ações preferenciais. ${ }^{37}$ Por analogia, as participações preferenciais em sociedades limitadas denominam-se cotas preferenciais.

A supressão ou restrição do direito de voto nas sociedades anônimas conta com expressa previsão legal e farta jurisprudência, estando, por isso mesmo, pacificada. Com relação às sociedades limitadas, porém, a questão não é tão simples. A intenção deste artigo é verificar se é possível adotar cotas preferenciais sem direito de voto na sociedade limitada, à luz da legislação ${ }^{38}$ em vigor.

\subsection{Vantagens e desvantagens das participações societárias preferenciais com restrição de voto}

Quem adquire participações societárias com restrição de voto normalmente pretende apenas auferir dividendos, não tendo interesse em participar da administração da sociedade. Por conseguinte, está disposto a renunciar ao direito de voto em troca de alguma vantagem, como, por exemplo, dividendo superior àquele pago aos sócios votantes.

\footnotetext{
${ }^{35}$ GUERREIRO, José Alexandre Tavares. Sociedade por Quotas - Quotas Preferenciais. Revista de Direito Mercantil, Industrial, Econômico e Financeiro. São Paulo: Malheiros, ano XXXIII, n. ${ }^{\circ}$ 94, p. 28-34, abr./jun. 1994. p. 28. "Com essa expressão, designam-se as partes de capital das sociedades em questão que, desprovidas do direito de voto, asseguram aos respectivos titulares determinadas vantagens, seja sob a forma de prioridade no recebimento de lucros, ou na restituição de capitais, seja por qualquer outra forma assemelhada."

${ }^{36}$ ANGELICI, Carlo; FERRI, Giovanni. Manuale di Diritto Commerciale. 12. ed. Torino: Utet Giuridica, 2006, p. 294. "Cosí possono essere create accanto ad azioni ordinarie, attribuenti cioè i normali diritti, azioni privilegiate, e cioè attribuenti un diritto di priorità (...); così possono essere create azioni senza diritto di voto, con voto limitato a particolari argomenti, con voto subordinato al verificarsi di particolari condizioni non meramente potestative (...)."

Igualmente: AULETTA, Giuseppe; SALANITRO, Niccolò. Diritto Commerciale. Milano: Giuffrè, 2003, p. 153 a 155.

${ }^{37}$ LAMY FILHO, Alfredo; BULHÕES PEDREIRA, José Luiz. Introdução. In: LAMY FILHO, Alfredo; BULHÕES PEDREIRA, José Luiz (Coord.).Direito das Companhias. Rio de Janeiro: Forense, 2009. v. I, p. 242. "Ação preferencial é a que confere a seu titular vantagens, patrimoniais e políticas, declaradas no estatuto, observados os requisitos e limites estabelecidos pela lei."

${ }^{38}$ Lembrando que "legislação" e "lei" não são sinônimos. A primeira é mais ampla, inclusive abrangendo a segunda, além de conter as previsões infralegais.
} 
Uma das vantagens desse tipo de participação é acomodar, no seio da sociedade, investidores com diferentes perfis, facilitando a captação de recursos ao mesmo tempo em que reduz os custos do investimento. ${ }^{39}$

Por outro lado, a sua principal desvantagem consiste em acirrar o conflito de interesses entre o controlador e os demais sócios ${ }^{40}$, ou mesmo intensificar a dissociação entre propriedade e controle ${ }^{41}$, dificultando a tomada de decisão.

\subsection{Ações preferenciais com restrição de voto, na legislação}

O Código Comercial de 1850 não disciplinava as restrições ao direito de voto das ações. Nessa época, a constituição de sociedades anônimas era um privilégio concedido pelo Governo, discricionariamente e por prazo determinado, cabendo a decisão a um órgão público, denominado Conselho de Estado. ${ }^{42}$ Então, era comum que o Conselho de Estado impusesse como condição para autorizar a constituição da sociedade - número máximo de votos por

${ }^{39}$ MOTA, Fernando de Andrade. Restrição do Direito de Voto na Sociedade Limitada. Revista de Direito Mercantil, Industrial, Econômico e Financeiro. São Paulo: Malheiros, ano LII, n. 164/165, p. 124-137, jan./ago. 2013, p. 135. "A restrição do direito de voto permite acomodar de forma mais fiel os diferentes interesses dos sócios das empresas, inclusive atribuindo vantagens particulares a sócios em qualquer hipótese, não poderiam prevalecer nas deliberações sociais. Adicionalmente, tal procedimento possibilita garantir maior estabilidade no contrato das sociedades, que pode ser desejável para os sócios como um todo."

Igualmente: WALD, Arnoldo. Do Direito de Empresa. In: TEIXEIRA, Sálvio de Figueiredo (Coord.). Comentários ao Novo Código Civil. Rio de Janeiro: Forense, 2005. v. 14, p. 360. "Assim como existem acionistas com interesses diferentes, alguns se importam com a gestão da companhia, outros tão-somente com os seus resultados. Na sociedade limitada também podem existir sócios com interesses contrapostos, que exigem instrumentos jurídicos aptos a regular as diferentes situações. Esta idéia não pode ser negada, em especial, frente a grande liberdade dada aos sócios para estabelecer os seus direitos e obrigações, bem como para determinar a forma da estrutura da sociedade."

${ }^{40}$ Sobre este tema, vide, por todos: HANSMANN, Henry; DAVIES, Paul; KRAAKMAN, Reinier R. et al. The Anatomy of Corporate Law: A Comparative and Functional Approach. Oxford: Oxford University Press, 2004.

${ }^{41}$ A respeito desse fenômeno e de suas consequências, consulte-se: BERLE JR., Adolf; MEANS, Gardiner C. The Modern Corporation and Private Property.7. ed. New Jersey: Transaction Publishers, 2005. Lembrando que o original desta obra foi publicado em 1932.

Também: ROE, Mark J. Strong Managers, Weak Owners: The Political Roots of American Corporate Finance. Princeton: Princeton University Press, 1994.

${ }^{42}$ BRASIL. Império. Lei $n^{\circ} 556$ de 25 de junho de 1850. Dispõe sobre o Código Comercial. In: Coleção de Leis do Brasil de 1850. Rio de Janeiro, RJ: 25 jun. 1850. "Art. 295. As companhias ou sociedades anônimas, designadas pelo objeto ou empresa a que se destinam, sem firma social, e administradas por mandatários revogáveis, sócios ou não sócios, só podem estabelecer-se por tempo determinado, e com autorização do Governo, dependente da aprovação do Corpo Legislativo quando hajam de gozar de algum privilégio: e devem provar-se por escritura pública, ou pelos seus estatutos, e pelo ato do Poder que as houver autorizado." 
acionista, independentemente da quantidade de ações que possuísse. ${ }^{43}$ Portanto, desde os primórdios, a sociedade anônima brasileira conviveu com restrições ao direito de voto dos acionistas, mesmo à míngua de disposição legal expressa.

Regulamentando esse Código, quando a constituição de S/A não mais dependia de autorização estatal, sobreveio o Decreto n. 434/1891. Ele não disciplinou expressamente as restrições ao direito de voto ${ }^{44}$, as quais eram então definidas por cada companhia, mediante previsão estatutária. Somente com o Decreto n. 21.536/1932 foram expressamente positivadas na legislação as ações preferenciais. ${ }^{45}$ Este decreto permitia, de forma genérica, que destas ações fosse suprimido ou restringido o direito de voto, sem, contudo, fixar patamares mínimos ou máximos.

Na sequência, a disciplina das sociedades anônimas foi retirada do Código Comercial, passando ao Decreto-Lei $n^{\circ} 2.627 / 1940$. Este, por sua vez, inseriu regramento mais detalhado

\footnotetext{
${ }^{43}$ PARGENDLER, Mariana. Cinco mitos sobre a história das sociedades anônimas no Brasil. In: KUYVEN, Luiz Fernando Martins (Coord.). Temas Essenciais de Direito Empresarial: Estudos em Homenagem a Modesto Carvalhosa. São Paulo: Saraiva, 2012, p. 871. “(...) as cláusulas estatutárias exigidas pelo Conselho de Estado quanto ao mecanismo de voto acionário dificultavam e até mesmo impediam que as companhias oitocentistas tivessem um acionista controlador."

44 BRASIL. República. Decreto $\mathrm{n}^{\circ} 434$ de 4 de julho de 1891. Consolida as disposições legislativas e regulamentares sobre as sociedades anonymas. In: Coleção de Leis do Brasil de 1891. Rio de Janeiro, RJ: 04 jul. 1891. "Art. 141. Nos estatutos se determinará a ordem, que se ha de guardar nas reuniões da assembléa geral, o numero mínimo de acções que é necessário aos accionistas para serem admittidos a votar em assembléa geral, e o numero de votos que compete a cada um na razão do numero de acções que possuir.

$\S 1^{\circ}$ Ainda que sem direito de votar, por não possuir o numero de acções exigido pelos estatutos, é permittido a todo o accionista comparecer á reunião da assembléa geral e discutir o objecto sujeito á deliberação."

${ }^{45}$ BRASIL. República. Decreto $n^{\circ} 21.536$ de 15 de junho de 1932. Dispõe sobre o modo de constituição do capital das sociedades anônimas, permitindo que ele se constitua, em parte, por ações preferenciais de uma ou mais classes. In: Diário Oficial da União. Rio de Janeiro, RJ: 15 jun. 1932. "Art. $1^{\circ} \mathrm{O}$ capital das sociedades anônimas pode ser, em parte, constituído por ações preferenciais de uma ou mais classes, observadas as disposições do presente decreto.

$\S 1^{\circ}$ A preferência pode consistir:

a) em prioridade na distribuição de dividendos, mesmo fixos e cumulativos;

b) em prioridade no reembolso do capital, com ou sem prêmio; c) na acumulação das vantagens acima enumeradas;

c) na acumulação das vantagens acima enumeradas.

(...)

$\S 3^{\circ}$ Os estatutos poderão deixar de conferir às ações preferenciais algum ou alguns dos direitos reconhecidos às ações comuns, inclusive o de voto, ou de conferí-los com restrições, não podendo, porem, impedir a seus possuidores a fiscalização dos atos da administração, tal como é, por lei, facultada aos acionistas comuns, nem thes vedar o direito de requerer a dissolução e a falência da sociedade, nos casos previstos em lei."
} 
acerca das ações preferenciais sem direito de voto, limitando-as a $50 \%$ do capital social ${ }^{46}$. 0 Decreto-Lei $n^{\circ} 2.627 / 1940$ foi sucedido pela atual LSA que, em sua redação originária, admitia até $2 / 3$ de ações preferenciais com restrição de voto. ${ }^{47}$

Atualmente, a LSA foi alterada pela Lei n. 10.303/2001, que reduziu a $50 \%$ do capital o percentual máximo de ações preferenciais com restrição de voto. ${ }^{48}$ Esta permissão expressa, aliada ao fato de que o voto não se inclui entre os "direitos fundamentais" do acionista, insuscetíveis de supressão pela assembleia-geral ou pelo estatuto ${ }^{49}$, pacificou de vez as discussões doutrinárias sobre o tema ${ }^{50}$. Hoje, não mais se questiona a possibilidade de ações preferenciais com restrição de voto, desde que observados os limites impostos pela própria LSA. Quando muito, discute-se se as preferências concedidas em troca seriam, de fato, proporcionais a essa restrição. ${ }^{51}$

Vale ressaltar, por fim, que o regulamento do Novo Mercado da BM\&FBovespa veda às companhias nele listadas a adoção de ações preferenciais, devendo o capital social ser

46 BRASIL. Congresso Nacional. Decreto-Lei n 2.627 de 26 de setembro de 1940. Dispõe sobre as sociedades por ações. Rio de Janeiro, RJ: 26 set. 1940. Disponível em: < http://www.planalto.gov.br/ccivil_03/decreto-lei/Del2627.htm>. “Art. 9. (...)

Parágrafo único. A emissão de ações preferenciais sem direito de voto não pode ultrapassar a metade do capital da companhia."

Vale lembrar que essa restrição foi rapidamente excepcionada em relação às sociedades cujo objeto era o aproveitamentos de quedas d'água destinado a serviços públicos, de utilidade pública ou ao comércio de energia (Decreto-Lei n. 852/1938 art. $6^{\circ}$ ), as quais poderiam ter seu capital composto por até $2 / 3$ de ações preferenciais sem direito de voto (Decreto-Lei n. 4.480/1942 art. $1^{\circ}$ ), bem como às companhias controladas pela União, Estados-membros e Municípios (Decreto-Lei n. 6.464/1944).

${ }^{47}$ BRASIL. Congresso Nacional. Lei $n^{\circ} 6.404$ de 15 de dezembro de 1976.Dispõe sobre as sociedades por ações. Diário Oficial da União. Brasília, DF: 15 dez. 1976. "Art. 15. (...).

$\S 2^{\circ} \mathrm{O}$ número de ações preferenciais sem direito a voto ou sujeitas a restrições no exercício desse direito, não pode ultrapassar $2 / 3$ (dois terços) do total das ações emitidas."

${ }^{48}$ BRASIL. Congresso Nacional. Lei $\mathrm{n}^{\circ} 6.404$ de 15 de dezembro de 1976.Dispõe sobre as sociedades por ações. Diário Oficial da União. Brasília, DF: 15 dez. 1976. "Art. 15. (...).

$\S 2^{\circ}$. O número de ações preferenciais sem direito a voto, ou sujeitas a restrição no exercício desse direito, não pode ultrapassar 50\% (cinqüenta por cento) do total das ações emitidas."

"Art. 111. O estatuto poderá deixar de conferir às ações preferenciais algum ou alguns dos direitos reconhecidos às ações ordinárias, inclusive o de voto, ou conferi-lo com restrições, observado o disposto no artigo 109.

(...)."

49 BRASIL. Congresso Nacional. Lei $n^{\circ} 6.404$ de 15 de dezembro de 1976. Dispõe sobre as sociedades por ações. Diário Oficial da União. Brasília, DF: 15 dez. 1976.. Art. 109.

50 Vide, por todos: BULGARELLI, Waldírio. Manual das Sociedades Anônimas. 7. ed. São Paulo: Atlas, 1993. p. 112. "As ações preferenciais caracterizam-se por conferir ao seu titular certas vantagens em comparação com as comuns ou ordinárias, mas que em regra são, em contrapartida, destituídas de outros direitos, como o de voto."

${ }^{51}$ RIBEIRO, Renato Ventura. Direito de Voto nas Sociedades Anônimas. São Paulo: Quartier Latin, 2009. p. 96. "As vantagens atribuídas às ações preferenciais, com ou sem voto, no direito brasileiro são irrisórias." 
composto, integralmente, por ações ordinárias com direito de voto. ${ }^{52}$ Trata-se de disposição excepcional, fundada em razões de governança corporativa.

\subsection{Cotas preferenciais com restrição de voto, na legislação}

Como se sabe, uma das principais diferenças entre a sociedade anônima e a limitada é que esta última não apresenta o capital divido em ações, mas sim em cotas, insuscetíveis de negociação no mercado de valores mobiliários. ${ }^{53}$ Disto decorre que a disciplina específica das ações somente se aplica às cotas mutatis mutandis, ou seja, naquilo em que for compatível com a natureza destas últimas.

A primeira lei pátria sobre sociedades limitadas, o Decreto n. 3.708/1919, nada dispunha acerca de eventuais restrições de voto. Na ausência de vedação legal, porém, essa prática era corriqueiramente adotada, bastando a previsão, no contrato social, de classes de cotas com restrição de voto. ${ }^{54}$ Como esse Decreto impunha às sociedades limitadas regência supletiva pela $\mathrm{LSA}^{55}$, deveriam ser observadas as prescrições desta última, aplicáveis às ações preferenciais. Por exemplo, o limite máximo de $50 \%$ do capital social para as cotas com restrição de voto.

Sobreveio, porém, o Código Civil de 2002, reavivando discussões até então superadas. Este Código não traz precisas disposições acerca das cotas com restrição de voto. Limita-se à

52 BRASIL. Bolsa de Valores, Mercadorias e Futuros - BM\&FBovespa. Regulamento do Novo Mercado. São Paulo: BM\&FBovespa. Disponível em: <http://www.bmfbovespa.com.br/Pdf/RegulamentoNMercado.pdf>. Acesso em: 29 nov. 2015. "3.1 Autorização para Negociação no Novo Mercado. O Diretor Geral da BOVESPA poderá conceder autorização para negociação no Novo Mercado para a Companhia que preencher as seguintes condições mínimas:

(...)

(vi) tenha seu capital social dividido exclusivamente em ações ordinárias, exceto em casos de desestatização, se se tratar de ações preferenciais de classe especial que tenham por fim garantir direitos políticos diferenciados, sejam intransferíveis e de propriedade do ente desestatizante, devendo referidos direitos ter sido objeto de análise prévia pela BOVESPA;"

${ }^{53}$ ABRÃO, Nelson. Sociedade por quotas de responsabilidade limitada. 5. ed. São Paulo: Revista dos Tribunais, 1995. p. 79-82. "Não tem procedência a assemelhação que se pretende estabelecer entre a quota e a ação da private company do direito inglês."

${ }^{54}$ GUERREIRO, José Alexandre Tavares. Sociedade por Quotas - Quotas Preferenciais. Revista de Direito Mercantil, Industrial, Econômico e Financeiro. São Paulo: Malheiros, ano XXXIII, n. ${ }^{\circ}$ 94, p. 28-34, $\mathrm{abr} /$ jun. 1994, p. 28. "A finalidade deste estudo é a de demonstrar que, no Brasil, perante o regime jurídico das sociedades por quotas de responsabilidade limitada [na vigência do Decreto n. 3.708/1919], são plenamente admissíveis as denominadas quotas preferenciais."

${ }_{55}$ BRASIL. Congresso Nacional. Decreto $n^{\circ} 3.719$ de 15 de janeiro de 1919. Corrige enganos com que foi publicada a lei n. 3.674, de 7 de janeiro de 1919. In: Diário Oficial da União. Rio de Janeiro, RJ: 15 jan. 1919. "Art. 18. Serão observadas quanto ás sociedades por quotas, de responsabilidade limitada, no que não for regulado no estatuto social, e na parte applicavel, as disposições da lei das sociedades anonymas." 
seguinte previsão genérica: “Art. 1.055. O capital social divide-se em quotas, iguais ou desiguais, cabendo uma ou diversas a cada sócio."

Com base nessa previsão lacunosa, formaram-se algumas correntes de pensamento. ${ }^{56} \mathrm{~A}$ primeira segue a tradição histórica do país, no sentido de admitir as cotas preferenciais com restrição de voto. ${ }^{57}$ Argumenta-se que o citado art. 1.055 permitiria isto. Ademais, o próprio Código Civil disciplinaria hipóteses de cotas desiguais, como, por exemplo, em relação à participação do sócio nos lucros ou nas perdas ${ }^{58}$. Argumenta-se, ademais, que o Código Civil de 1916, quando desejou conferir direito de voto a todos os sócios, o fez de forma expressa. ${ }^{59} \mathrm{~A}$ contrario sensu, o Código revogado permitiu que houvesse restrições ao voto, previstas no

\footnotetext{
${ }^{56}$ Para um breve resumo dessas correntes, consulte-se: AMENDOLARA, Leslie. Os Direitos dos Minoritários na Sociedade Limitada. São Paulo: Quartier Latin, 2006, p. 59 a 61.

${ }^{57}$ MOTA, Fernando de Andrade. Restrição do Direito de Voto na Sociedade Limitada. Revista de Direito Mercantil, Industrial, Econômico e Financeiro. São Paulo: Malheiros, ano LII, n. 164/165, p. 124-137, jan./ago. 2013, p. 132; 136. "O CC, além de não afirmar a igualdade de direitos dos sócios, prevê, no art. 1.055 , que o capital social se divide em quotas, iguais ou desiguais.
}

(...)

Conclui-se, dessa forma, não haver óbice legal à restrição do direito de voto nas sociedades limitadas desde que observados alguns limites mínimos. Sua adoção estará situada sempre na esfera de disposição privada, em que caberá às partes sopesar seus prós e contras para decidir a respeito de sua conveniência."

WALD, Arnoldo. Do Direito de Empresa. In: TEIXEIRA, Sálvio de Figueiredo (Coord.). Comentários ao Novo Código Civil. Rio de Janeiro: Forense, 2005. v. 14, p. 358; 360. "O caput do artigo 1055 estabelece que as quotas podem ser iguais ou desiguais. Ao assim dispor, de forma simples e genérica, o novo Código Civil mantém o princípio da ampla liberdade para estabelecer no contrato social os direitos e as obrigações de cada sócio, obedecendo apenas, aos limites impostos pelas regras cogentes e princípio do direito societário e respeitando os direitos inderrogáveis.

(...)

Entendemos que o Novo Código Civil estabelecendo que as quotas podem ser iguais ou desiguais, também permite a criação de quotas preferenciais, embora talvez não seja essa a intenção do legislador. Mas a 'mens legis' deve prevalecer sobre a 'mens legislatoris'."

PATROCÍNIO, Daniel Moreira do. Sociedade Limitada: Comentários. São Paulo: Juarez de Oliveira, 2008, p. 26. "Cremos que será possível, mediante ajuste social, a existência de quotas sem direito de voto, (...) de forma semelhante àquela estabelecida no art. 17, da Lei n. 6.404, de 1976, que cuida das denominadas ações preferenciais."

58 BRASIL. Congresso Nacional. Código Civil. Brasília: 10 jan. 2002. "Art. 1.007. Salvo estipulação em contrário, o sócio participa dos lucros e das perdas, na proporção das respectivas quotas, mas aquele, cuja contribuição consiste em serviços, somente participa dos lucros na proporção da média do valor das quotas."

DE LUCCA, Newton. Texto introdutório ao Livro II - Do Direito de Empresa. In: ALVIM, Arruda; ALVIM, Thereza (Coord.). Comentários ao Código Civil Brasileiro: Do Direito de Empresa. Rio de Janeiro: Forense, 2005. v. IX, p. 322. "Note-se que o art. 1007 dispõe que o contrato social pode prever participações distintas dos sócios nos lucros e nas perdas, o que representa exatamente a possibilidade de ter quotas com direitos distintos".

${ }^{59}$ BRASIL. Congresso Nacional. Lei $n^{\circ} 3.071$ de $1^{\circ}$ de janeiro de 1916. Código Civil. Diário Oficial da União. Rio de Janeiro, RJ: 01 jan. 1916. "Art. 1.394. Todos os sócios têm direito de votar nas assembléias gerais, onde, salvo estipulação em contrario, sempre se deliberará por maioria de votos." 
contrato social, devendo a novel legislação ser interpretada no sentido da continuidade dessa prática.

Confirmando este raciocínio, durante a tramitação legislativa do Código Civil de 2002 no Senado, o Senador Gabriel Hermes apresentou a Proposta de Emenda n. 87, que pretendia inserir na lei a seguinte previsão: “Art. 1.058. [...] $\S 3^{\circ} \mathrm{O}$ contrato pode permitir a criação de quotas que assegurem a seus titulares preferência no recebimento de lucros apurados em balanço, ou na liquidação da sociedade, com ou sem direito de voto."

Ocorre que essa emenda foi rejeitada, ao argumento de que seria desnecessária, porque o caput do art. 1.055 , supostamente, já permitiria a adoção de cotas preferenciais. ${ }^{60}$

Outros ponderam que as cotas desiguais do art. 1.055 poderiam ser interpretadas apenas como autorização para a desequiparação quanto ao valor de cada $\operatorname{cota}^{61}$, não quanto aos direitos e deveres que conferem.

Por outro lado, a corrente de pensamento que ganhou mais força após a vigência do Código Civil de 2002 é a que considera inadmissível a cota preferencial com restrição de voto. ${ }^{62}$

60 PASSOS, Edilenice; LIMA, João Alberto de Oliveira. Memória Legislativa do Código Civil: Tramitação no
Senado Federal. Brasília: Senado Federal, 2012. V. 3. Disponível em: <http://www.senado.gov.br/publicacoes/mlcc/pdf/mlcc_v3_ed1.pdf>. Acesso em 10 ago. 2015, p. 62.

${ }^{61}$ LUCENA, José Waldecy. Das Sociedades Limitadas. 6. ed. Rio de Janeiro: Renovar, 2005, p. 322-323. “(...) os sócios podem atribuir a cada quota o valor que thes convier, presente que, em nosso ordenamento jurídico, não há imposição de um valor nominal à quota, seja fixo, seja mínimo. Omissos, a respeito, foram o Decreto n 3.708, o Código Comercial e o Código Civil de 1916, tal como hoje o são a Lei das Anônimas e o novo Código Civil. E, assim obrando, fizeram-no com acerto."

GALIZZI, Gustavo Oliva; CAMARGO, Diogo Tressoldi. Investimento de Terceiro na Sociedade Limitada Familiar: Regulação do Poder de Controle. In: COELHO, Fábio Ulhoa; FÉRES, Marcelo Andrade (Coord.). Empresa Familiar: estudos jurídicos. São Paulo: Saraiva, 2014, p. 231. "Por isso, quando admite, no art. 1055, caput, do Código Civil, a existência de 'quotas iguais ou desiguais, cabendo uma ou diversas a cada sócio', o legislador está se referindo ao valor, igual ou desigual, que representa o montante do investimento do sócio à época de sua aquisição, bem como os demais investimentos feitos de tempos em tempos."

Também: BORBA, José Edwaldo Tavares. Direito Societário. 9. ed. Rio de Janeiro: Renovar, 2004, p. 113114.

62 LOBO, Jorge. Sociedades Limitadas. Rio de Janeiro: Forense, 2004. v. 1, p. 144. "As quotas preferenciais terão sempre direito de voto, além dos benefícios, vantagens e privilégios especificados no contrato social (...)."

TOKARS, Fábio Leandro. Sociedades Limitadas. São Paulo: LTr, 2007, p. 146. “Todos os sócios têm direito a voto nas sociedades limitadas. Não se encontra, nesta espécie societária, participações societárias assemelhadas às ações preferenciais das sociedades anônimas, em que se permite a restrição ou a eliminação do direito de voto em contrapartida às vantagens econômicas às mesmas vinculadas. $\mathrm{Na}$ sociedade limitada, todos os quotistas têm o mesmo status, não havendo quotas preferenciais."

CAMPINHO, Sérgio. O Direito de empresa: À Luz do Novo Código Civil. 11. ed. Rio de Janeiro: Renovar, 2010, p. 165. "Não podemos deixar de registrar nossa opinião contrária à possibilidade de adoção de quotas preferenciais, isto é, quotas diferenciadas que garantam certas preferências no exercício de determinados direitos aos seus titulares." 
0 principal argumento neste sentido é o de que o Código Civil, ao se referir às sociedades, em momento algum utiliza a expressão "capital votante", como faz a LSA, em inúmeras oportunidades. Pelo contrário, o Código refere-se apenas a "capital” ou, quando muito, a “capital social". Infere-se, destarte, que todas as cotas votam, porque todas compõem o capital social. $^{63}$

Esse argumento é reforçado pela regra do art. $1.010^{64}$, que dispõe que todas as cotas, independentemente de seu valor, votam nas deliberações sociais, acrescentando, ainda, que, para os fins do Código, maioria absoluta corresponde a mais da metade de todo o capital social. Logo se percebe, então, que se o capital social fosse composto por $50 \%$ de cotas preferenciais, sem direito de voto, seria impossível alcançar a maioria absoluta exigida pela lei. Acrescente-se o fato de que o Código Civil também fixou, como obrigatórios, quóruns bastante elevados, como o de $3 / 4^{65}$. Neste caso, havendo mais de $25 \%$ do capital social composto por cotas preferenciais sem voto, também seria impossível preencher esses quóruns. Por tais razões, a terceira corrente considera que o voto, na sociedade limitada, é um direito essencial do acionista, insuscetível de ser restringido pelo contrato social.

Finalmente, o Projeto de Novo Código Comercial que tramita no Senado enfrenta o assunto com clareza, tomando posição no sentido de admitir as cotas preferenciais, inclusive com restrição de voto:

Art. 306. O contrato social pode instituir quotas preferenciais que atribuam a seus titulares a prioridade no recebimento de dividendos mínimos, fixos ou diferenciais, cumulativos ou não, ou para thes conferir o direito de eleger um dos administradores.

$\S 1^{\circ}$. A outorga de qualquer das vantagens previstas neste artigo pode ser por prazo determinado ou indeterminado.

BOTREL, Sérgio. Fusões \& Aquisições. 3. ed. São Paulo: Saraiva, 2014, p. 158. "Em que pese haver dissidência sobre o tema, tem prevalecido o entendimento, inclusive endossado por várias Juntas Comerciais, de que o direito de voto é um direito essencial inerente ao status de sócio de uma sociedade limitada."

${ }^{63}$ MOTA, Fernando de Andrade. Restrição do Direito de Voto na Sociedade Limitada. Revista de Direito Mercantil, Industrial, Econômico e Financeiro. São Paulo: Malheiros, ano LII, n. 164/165, p. 124-137, jan./ago. 2013, p. 132. "Outro argumento colocado contra a emissão de quotas preferenciais fundamentase nas previsões legais que definem o capital social - e não as quotas votantes - como critério para a determinação de quorum (...)."

${ }^{64}$ BRASIL. Congresso Nacional. Código Civil. Brasília: 10 jan. 2002. "Art. 1.010. Quando, por lei ou pelo contrato social, competir aos sócios decidir sobre os negócios da sociedade, as deliberações serão tomadas por maioria de votos, contados segundo o valor das quotas de cada um.

$\S 1^{\circ}$. Para formação da maioria absoluta são necessários votos correspondentes a mais de metade do capital."

${ }^{65}$ BRASIL. Congresso Nacional. Código Civil. Brasília: 10 jan. 2002. Art. 1.074, caput e 1.076, I. 
$\S 2^{\circ}$. O contrato social pode estabelecer a supressão ou limitação do exercício do direito de voto pelo sócio titular de quotas preferenciais.

$\S 3^{\circ}$. O número de quotas preferenciais com supressão ou limitação do direito de voto não pode superar a metade do capital social.

$\S 4^{\circ}$. O sócio titular de quotas preferenciais, com direito de voto suprimido ou limitado, readquire o seu exercício quando as vantagens previstas no contrato social não se tornarem efetivas por três exercícios sociais consecutivos. ${ }^{66}$

Caso esse projeto venha a ser converter em lei, e caso esse artigo seja mantido, ficará absolutamente claro que a restrição às cotas preferenciais marcou um momento atípico na história do Direito Societário brasileiro, motivado, em grande medida, pelo lacunoso e equivocado tratamento dado ao tema pelo Código Civil de 2002.

Finalmente, há que se destacar o fato de que, se admitidas, as cotas com restrição de voto devem adquirir esse direito, em sua plenitude, nos mesmos casos em que as ações preferenciais o fariam. Por exemplo, nas deliberações que pretendem alterar as vantagens das ações preferenciais ${ }^{67}$, ou quando a companhia deixar de pagar os dividendos a que estes acionistas fizerem jus, por prazo superior ao previsto no estatuto, limitado a três exercícios financeiros. ${ }^{68}$

Cumpre, agora, analisar como os órgãos de registro empresarial vêm lidando, na prática, com essa questão.

\subsection{Posicionamento do DNRC e do DREI}

Se na doutrina há dissenso acerca do cabimento das cotas preferenciais, notadamente daquelas com restrição de voto, na prática os órgãos de registro empresarial pacificaram a questão (como não poderia deixar de ser, a bem da previsibilidade e segurança jurídica do sistema registral). Como se demonstrará nas linhas seguintes, antes da entrada em vigor do

\footnotetext{
${ }^{66}$ BRASIL. Senado Federal. Projeto de Lei n. 487. Autor: Senador Renan Calheiros. Brasília: 22 nov. 2013.

${ }^{67}$ BRASIL. Congresso Nacional. Lei n 6.404. Brasília: 15 dez. 1976. "Art. 136. (...)

§ $1^{\circ}$ Nos casos dos incisos I e II, a eficácia da deliberação depende de prévia aprovação ou da ratificação, em prazo improrrogável de um ano, por titulares de mais da metade de cada classe de ações preferenciais prejudicadas, reunidos em assembléia especial convocada pelos administradores e instalada com as formalidades desta Lei."

${ }^{68}$ BRASIL. Congresso Nacional. Lei $n^{\circ} 6.404$ de 15 de dezembro de 1976.Dispõe sobre as sociedades por ações. Diário Oficial da União. Brasília, DF: 15 dez. 1976. "Art. 111. (...)

$\S 1^{\circ}$ As ações preferenciais sem direito de voto adquirirão o exercício desse direito se a companhia, pelo prazo previsto no estatuto, não superior a 3 (três) exercícios consecutivos, deixar de pagar os dividendos fixos ou mínimos a que fizerem jus, direito que conservarão até o pagamento, se tais dividendos não forem cumulativos, ou até que sejam pagos os cumulativos em atraso."
} 
Código Civil de 2002 as cotas preferenciais eram admitidas a registro. Com o atual Código, porém, foram terminantemente proibidas, mesmo aquelas que não importem restrição ao direito de voto.

Já foi dito que o Decreto n. 3.708/1919 era omisso quanto ao tema. Assim, na prática, foram surgindo e sendo regularmente registrados contratos de sociedade limitada prevendo cotas preferenciais, principalmente após a regulamentação das ações preferenciais pelo Decreto n. 21.536/1932, tendo em vista a regência supletiva das limitadas pela legislação das sociedades por ações. Nas décadas de 70 e 80 esse posicionamento já estava pacificado, como demonstram os pareceres da Procuradoria Especializada da Junta Comercial do Estado de São Paulo:

Destamaneira, quer nos parecer s. m. j., que o regime das ações preferenciais pode legalmente ser adotado nas sociedades limitadas, independentemente de se discutir se este tipo societário é de capital ou de pessoas. Assim, é lícito aos contratantes criar espécie diferenciada de quota ou parte social, com uma ou todas as preferencias ou privilégios de ordem econômica ou política indicados na lei das sociedades por ações. ${ }^{69}$

"No silêncio das sociedades limitadas, a doutrina entende a adoção de quotas preferenciais nesse tipo societário.”70

Porém, o Código Civil de 2002 alterou profundamente esse cenário. Tanto que o Manual de Atos de Registro de Sociedade Limitada, editado pelo Departamento Nacional de Registro do Comércio - DNRC, logo após a entrada em vigor do Código, passou a proibir, peremptoriamente, quaisquer cotas preferenciais, houvesse ou não restrição de voto: “1.2.16.3 - Quota preferencial.Não cabe para sociedade limitada a figura da quota preferencial."71

Tal entendimento é o que perdura até hoje, pois a norma do $\mathrm{DREl}^{72}$ repete, literalmente, a citada proibição. ${ }^{73}$ Portanto, o registro público empresarial optou por interpretar

\footnotetext{
${ }^{69}$ BRASIL. Junta Comercial do Estado de São Paulo. Parecer n 71/1978. Boletim JUCESP.São Paulo: Diário Oficial do Estado de São Paulo, v. 91, n. 158, 1981.

${ }^{70}$ BRASIL. Junta Comercial do Estado de São Paulo. Parecer n 137/1981. Boletim JUCESP.São Paulo: Diário Oficial do Estado de São Paulo, v. 91, n. 158, 1981.

${ }^{71}$ BRASIL. Departamento Nacional de Registro do Comércio - DNRC. Instrução Normativa $n^{\circ}$ 98/2003 (Manual de Atos de Registro de Sociedade Limitada). Brasília: DNRC. Disponível em <http://drei.smpe.gov.br/legislacao/instrucoes-normativas/titulo-menu/pasta-instrucoes-normativas-emvigor-02-1/instrucao-normativa-no-98-de-23-de-dezembro-de-2003>. Acesso em: 30 nov. 2015.

72 Lembrando que o DREl é o órgão de registro empresarial que sucedeu o DNRC.

${ }^{73}$ BRASIL. Departamento de Registro Empresarial e Integração - DREI. Instrução Normativa $n^{\circ}$ 10/2013 (Manual de Atos de Registro de Sociedade Limitada). Brasília: DREl. Disponível em <http://drei.smpe.gov.br/legislacao/instrucoes-normativas/titulo-menu/pasta-instrucoes-normativas-emvigor-04/in102013anexo2-manual-de-registro-sociedade-limitada-08-09-2014.pdf >. Acesso em: 30 nov. 2015. Item 1.2.16.3.
} 
o Código Civil de 2002 de forma conservadora, rompendo com a tradição histórica então existente, a fim de proibir as cotas preferenciais. É bem verdade que esse entendimento não escapa de críticas, até mesmo com relação a sua legalidade, por instituir restrição não prevista expressamente em lej $^{74}$, além de conflitar com os princípios constitucionais da autonomia da vontade, da livre iniciativa e da livre concorrência.

\subsection{Posição dos Autores}

Feito o registro acerca da evolução histórica do tema no país, tanto do ponto de vista legislativo quanto doutrinário, além do entendimento dos órgãos de registro empresarial, cumpre, agora, externar a posição dos autores deste texto.

Com efeito, entende-se que na ausência de vedação legal expressa não poderiam os órgãos de registro, via norma infralegal, suprimir, pura e simplesmente, a faculdade de prever quaisquer tipos de cotas preferenciais em contratos de sociedade limitada. Como mencionado, além de ilícito isto se revela inconstitucional. Até porque nem toda cota preferencial teria, obrigatoriamente, supressão do direito de voto.

Por outro lado, as cotas preferenciais com supressão ou restrição desse direito realmente não são admissíveis, ao menos segundo a redação atual do Código Civil. Inicialmente, por uma razão de fato. Nas deliberações para as quais há quórum definido em lei, como alguns deles são elevados, alcançando $3 / 4$ do capital social ${ }^{75}$, seria impossível preenchê-los caso mais de $25 \%$ do capital total fosse composto por cotas sem direito de voto. Até mesmo a instalação da assembleia geral seria dificultada, visto que seu quórum primário também é de $3 / 4 .{ }^{76}$

0 mesmo se diga em relação às deliberações obrigatórias apenas por força de cláusula do contrato social, com base na autonomia da vontade dos contratantes e no princípio majoritário. Nestas, a fixação de quóruns reduzidos até seria teoricamente compatível com a existência de cotas preferenciais sem direito de voto. Todavia, a literalidade do Código Civil

\footnotetext{
${ }^{74}$ MOTA, Fernando de Andrade. Restrição do Direito de Voto na Sociedade Limitada. Revista de Direito Mercantil, Industrial, Econômico e Financeiro. São Paulo: Malheiros, ano LII, n. 164/165, p. 124-137, jan./ago. 2013, p. 130. “(...) cabe reconhecer que, efetivamente, a legislação não conferia ao DNRC, nem tampouco confere ao DREI, poderes para tolher a liberdade contratual, proibindo a emissão de quotas preferenciais, se o Código Civil não o fez."

Igualmente: SIMIONATO, Frederico A. Monte. Tratado de Direito Societário. Rio de Janeiro: Forense, 2009. v. I. p. 602. “(...) esse 'Manual' é a consagração da burocracia brasileira em nível máximo, e não pode tolher a liberdade nos contratos, sempre que tenha objeto lícito e agente capaz."

${ }^{75}$ Vide Código Civil art. 1.076, I.

${ }^{76}$ Vide Código Civil art. 1.074.
} 
veda a restrição ao direito de voto, inclusive em relação às deliberações puramente contratuais. Isto porque o art. 1.010, caput $^{77}$, é absolutamente claro ao determinar que "as deliberações serão tomadas por maioria de votos, contados segundo o valor das quotas de cada um" (ou seja, todas as cotas podem votar). E o mesmo dispositivo evidencia que isto se aplica tanto às deliberações impostas por lei quanto àquelas previstas exclusivamente no contrato social ("quando, por lei ou pelo contrato social, competir aos sócios decidir sobre os negócios da sociedade"). Aspecto ainda ratificado por dispositivo específico das sociedades limitadas, o art. 1.071, caput, que remete às deliberações sobre "matérias indicadas na lei ou no contrato".

Em suma, todas as cotas podem votar em quaisquer deliberações da sociedade limitada, sejam elas obrigatórias por lei ou por disposição do contrato social, salvo excepcional vedação para o exercício do direito de voto, prevista em lei, para casos específicos. Por exemplo, na assembleia destinada a deliberar acerca da exclusão extrajudicial de cotista minoritário ${ }^{78}$, é evidente que este não deve votar, até porque se pressupõe haver conflito formal de interesses.

Dito isto, passa-se ao exame das cotas sem direito de voto nos EUA.

\section{COTAS SEM DIREITO DE VOTO NOS EUA}

Já foi dito, por ocasião da parte histórica, que o surgimento das sociedades limitadas nos EUA (limited liability company - LLC) se deu de forma bastante tardia em relação aos países europeus e sul-americanos. Além do atraso temporal, os EUA também demoraram um pouco mais para desvendar a real natureza desse tipo societário. Com efeito, inicialmente entendia-se que a LLC se aproximava da general partnership, no sentido de que todos os sócios teriam direito de voto e os votos seriam computados per capta, ao invés de se basear no valor das $\operatorname{cotas}^{79}$. Nessa

\footnotetext{
77 BRASIL. Congresso Nacional. Código Civil. Brasília: 10 jan. 2002. "Art. 1.010. Quando, por lei ou pelo contrato social, competir aos sócios decidir sobre os negócios da sociedade, as deliberações serão tomadas por maioria de votos, contados segundo o valor das quotas de cada um.(...)"

${ }_{78}$ Note-se que o texto legal menciona "exercício do direito de defesa", não o voto: BRASIL. Congresso Nacional. Código Civil. Brasília: 10 jan. 2002. "Art. 1.085. Ressalvado o disposto no art. 1.030, quando a maioria dos sócios, representativa de mais da metade do capital social, entender que um ou mais sócios estão pondo em risco a continuidade da empresa, em virtude de atos de inegável gravidade, poderá excluí-los da sociedade, mediante alteração do contrato social, desde que prevista neste a exclusão por justa causa.

Parágrafo único. A exclusão somente poderá ser determinada em reunião ou assembléia especialmente convocada para esse fim, ciente o acusado em tempo hábil para permitir seu comparecimento e o exercício do direito de defesa."

${ }^{79}$ RUTLEDGE, Thomas E. Allocating Voting and Economic Rights in LLC: An Invitation to Confusion. Journal of Passthrough Entities.New York: CCH Incorporated. v. 16, n. 06, p. 69-75, Nov./Dec. 2013, p. 69. “The
} 
época, a utilização de cotas preferenciais com restrição de voto (nonvoting membership interests) não faria sentido, pois o cômputo dos votos nas deliberações sociais independeria da quantidade e da espécie de cotas de cada sócio.

Somente após o paulatino desenvolvimento da LLC nos EUA e a compreensão de que se tratava de um tipo societário com características próprias, inconfundível com qualquer dos tipos até então predominantes (partnership e corporation) ${ }^{80}$, é que passaram a ser discutidas questões mais específicas sobre ela, tais como o voto proporcional ao investimento (hoje convertido em regra, na maior parte das leis estaduais) ${ }^{81}$, além da possibilidade de cotas sem direito de voto, visto que esse tipo de participação societária tem alcance bastante reduzido na corporation ${ }^{82}$.

Tendo em vista os limites desta pesquisa, aspectos jurisprudenciais e doutrinários sobre a LLC não serão analisados. As linhas seguintes concentram-se em descrever, de maneira breve, como o tema é tratado na legislação. Mais especificamente, na "lei uniforme" (Revised Uniform Limited Liability Company Act - RULLCA) ${ }^{83}$ e na legislação estadual de Delaware (Delaware LLC Act). ${ }^{84}$

earliest LLC Acts, reflecting their origin in partnership law, typically provided that members would vote and participate in the proceeds of the venture on a per capita basis. Under these formulae, there existed little opportunity for disputes as to the allocation of voting authority and economic rights; count the total number of members to derive the total number of possible votes and shares."

${ }^{80}$ RUTLEDGE, Thomas E. Let's Stop Describing LLCs as "Hybrids". Journal of Passthrough Entities. New York: CCH Incorporated. v. 33, n. 01, p. 33-38, Sep./Oct. 2014, p. 33 e 34. "In today's environment, the LLC, like each other form of business organization, must be understood as a unique construct of formulae and characteristics that may or may not be shared with other organizational forms.

(...)

The LLC is intended to provide a different answer to certain questions, to provide an alternative organizational paradigm that was not available under the previously available forms such as the partnership and the corporation.

(...)

In the end, an LLC is simply that - it is an LLC in the same way that a corporation is a corporation and a partnership is a partnership."

${ }^{81}$ RUTLEDGE, Thomas E. Allocating Voting and Economic Rights in LLC: An Invitation to Confusion. Journal of Passthrough Entities. New York: CCH Incorporated. v. 16, n. 06, p. 69-75, Nov./Dec. 2013, p. 69; 70. "Since the early days of the LLC, most LLC Acts have moved away from the default rule of per capita voting and sharing, adopting formulae tied to capital or other financial measure."

${ }^{82}$ RIBEIRO, Renato Ventura. Direito de Voto nas Sociedades Anônimas. São Paulo: Quartier Latin, 2009. p. 92. "Nos Estados Unidos, apesar de permitidas desde o século XIX, as ações sem direito de voto (votless shares) passaram a ser pouco utilizadas, em razão de sua pouca aceitação no mercado, em especial segundo as regras da Bolsa de Valores de Nova York, que desde 1926 não admite à negociação ações ordinárias sem direito de voto e, a partir de 1940, também as demais ações sem direito de voto."

${ }^{83}$ UNITED STATES OF AMERICA. Uniform Law Commission. Revised Uniform Limited Liability Company Act - RULLCA.Disponível em: <http://www.uniformlaws.org/>. Acesso em: 02 dez. 2015.

84 UNITED STATES OF AMERICA. Delaware Department of State. Delaware Limited Liability Company Act.Disponível em: <http://delcode.delaware.gov/title6/c018/>. Acesso em: 02 dez. 2015. 
Vale frisar que a LLC, assim como ocorria com as sociedades limitadas brasileiras na vigência do Decreto n. 3.708/1919, é amplamente baseada na autonomia da vontade dos sócios, permitindo que eles definam, contratualmente e com liberdade, os aspectos referentes ao funcionamento interno da sociedade. É fato que existem algumas regras cogentes nas diversas legislações estaduais (LLC Statute Acts). Porém, estas regras costumam ser em número muito mais reduzido do que as contidas nas leis sobre sociedades anônimas. Destarte, na legislação sobre LLC predominam normas supletivas, aplicáveis apenas se os sócios não dispuserem sobre o tema, no contrato social (operating agreement). ${ }^{85}$

Neste contexto, cabe ao próprio contrato social definir os aspectos referentes ao exercício do direito de voto (membership voting rights), inclusive para, se for o caso, restringi-lo ou suprimi-lo ${ }^{86}$. Assim, é plenamente possível que o contrato social fixe um voto para cada sócio, independentemente de sua participação no capital social (votação per capta, algo incomum para a realidade brasileira). Ou que os votos sejam proporcionais à quantidade de cotas que cada sócio possui. Ou, ainda, que se opte por regra diversa, com quantidade diferente de votos para sócios com idêntica participação no capital social, desde que respeitados os limites da respectiva legislação estadual. ${ }^{87}$ Admite-se até mesmo a completa supressão do direito de voto de algum cotista.

${ }^{85}$ UNITED STATES OF AMERICA. Uniform Law Commission. Revised Uniform Limited Liability Company Act - RULLCA.Disponível em: <http://www.uniformlaws.org/>. Acesso em: 02 dez. 2015. "Section 110. Operating Agreement; Scope, Function, and Limitations. (...).

(b) To the extent the operating agreement does not otherwise provide for a matter described in subsection (a), this [act] governs the matter."

${ }^{86}$ UNITED STATES OF AMERICA. Uniform Law Commission. Revised Uniform Limited Liability Company Act - RULLCA.Disponível em: <http://www.uniformlaws.org/>. Acesso em: 02 dez. 2015. "Section 110. Operating Agreement; Scope, Function, and Limitations. “(a) Except as otherwise provided in subsections (b) and (c), the operating agreement governs:

(1) relations among the members as members and between the members and the limited liability company;

(2) the rights and duties under this [act] of a person in the capacity of manager;

(3) the activities of the company and the conduct of those activities; and

(4) the means and conditions for amending the operating agreement."

UNITED STATES OF AMERICA. Delaware Department of State. Delaware Limited Liability Company Act. Disponível em: <http://delcode.delaware.gov/title6/c018/>. Acesso em 02 dez. 2015. "§ 18-215 Series of members, managers, limited liability company interests or assets.

(...)

(e) (...) A limited liability company agreement may provide that any member or class or group of members associated with a series shall have no voting rights."

${ }^{87}$ UNITED STATES OF AMERICA. Delaware Department of State. Delaware Limited Liability Company Act. Disponível em: <http://delcode.delaware.gov/title6/c018/>. Acesso em: 02 dez. 2015. "§ 18-215 Series of members, managers, limited liability company interests or assets. (...)

(f) A limited liability company agreement may grant to all or certain identified members or managers or a specified class or group of the members or managers associated with a series the right to vote separately 
Fato é que, no atual sistema norte-americano, as discussões travadas no Brasil, após a entrada em vigor do Código Civil de 2002, acerca das cotas preferenciais com restrição de voto, não têm grande relevância. A prevalência da autonomia da vontade na configuração interna desse tipo societário tem permitido aos EUA vivenciar exponencial crescimento no número de LLC's, sendo improvável que seus Estados-membros venham a adotar, no curto prazo, regras cogentes rígidas para as sociedades limitadas. Mais uma evidência de que a opção do Código Civil brasileiro, por burocratizar esse tipo societário, foi um grande erro.

Curioso notar, ainda, que o contrato de sociedade limitada, nos EUA, ao contrário do que sucede no Brasil, pode ser também verbal. ${ }^{88}$ Apesar desta permissão, é altamente recomendável que ele seja redigido por escrito, a fim de documentar e esclarecer certas situações, principalmente aquelas mais delicadas, como o exercício do direito de voto. Até porque o contrato social vinculará inclusive os sócios que ingressarem posteriormente na sociedade, não tendo participado da sua elaboração, e que, portanto, podem não concordar com os seus termos. Neste contexto, será mais simples vinculá-los às disposições constantes de prévio instrumento escrito.

or with all or any class or group of the members or managers associated with the series, on any matter. Voting by members or managers associated with a series may be on a per capita, number, financial interest, class, group or any other basis."

${ }^{88}$ UNITED STATES OF AMERICA. Uniform Law Commission. Revised Uniform Limited Liability Company Act - RULLCA.Disponível em: <http://www.uniformlaws.org/>. Acesso em: 02 dez. 2015. Section 102. Definitions. In this [act]: (...)

(13) 'Operating agreement' means the agreement, whether or not referred to as an operating agreement and whether oral, in a record, implied, or in any combination thereof, of all the members of a limited liability company, including a sole member, concerning the matters described in Section 110(a). The term includes the agreement as amended or restated."

UNITED STATES OF AMERICA. Delaware Department of State. Delaware Limited Liability Company Act.Disponível em: <http://delcode.delaware.gov/title6/c018/>. Acesso em: 02 dez. 2015. "§ 18-101 Definitions. As used in this chapter unless the context otherwise requires:(...)

(7) 'Limited liability company agreement" means any agreement (whether referred to as a limited liability company agreement, operating agreement or otherwise), written, oral or implied, of the member or members as to the affairs of a limited liability company and the conduct of its business. A member or manager of a limited liability company or an assignee of a limited liability company interest is bound by the limited liability company agreement whether or not the member or manager or assignee executes the limited liability company agreement. A limited liability company is not required to execute its limited liability company agreement. A limited liability company is bound by its limited liability company agreement whether or not the limited liability company executes the limited liability company agreement. A limited liability company agreement of a limited liability company having only 1 member shall not be unenforceable by reason of there being only 1 person who is a party to the limited liability company agreement. A limited liability company agreement is not subject to any statute of frauds (including $\$ 2714$ of this title). A limited liability company agreement may provide rights to any person, including a person who is not a party to the limited liability company agreement, to the extent set forth therein." 
Por fim, registre-se que as cotas preferenciais com restrição de voto não se confundem com o instituto da limited liability series - SLLC. Estas são extremamente úteis, interessantes e representam, atualmente, o ápice da evolução histórica da sociedade limitada norte-americana. Consubstanciam, no entanto, assunto a ser abordado em outra oportunidade, por meio de pesquisa específica.

\section{CONCLUSÃO}

$\mathrm{Na}$ esteira da Alemanha e de outros países europeus, o Brasil foi um dos primeiros Estados sul-americanos a legislar sobre as sociedades limitadas, já em 1919. Desde então, este novo tipo societário mostrou-se um grande sucesso. Muito em virtude da maneira pela qual era tratado na legislação, com poucas e objetivas regras cogentes, reservando-se a maior parte da estruturação do empreendimento, sobretudo em seus aspectos internos, à autonomia da vontade dos sócios, manifestada por meio do contrato social. Nessa época, era plenamente cabível a adoção de cotas preferenciais, inclusive com restrições ao direito de voto, mediante regência supletiva da LSA.

Todavia, o Código Civil de 2002 alterou profundamente esse panorama, ao impor tratamento legislativo burocrático e complexo às sociedades limitadas, na contramão das razões históricas que motivaram a criação deste tipo societário. Hoje, após mais de uma década da entrada em vigor deste Código, fica absolutamente claro que o tratamento por ele dispensado às sociedades limitadas foi um erro. Uma das consequências deste erro foi inviabilizar, por vias transversas, a adoção de cotas preferenciais com restrição ao direito de voto.

Curiosamente, os Estados Unidos da América legislaram pela primeira vez sobre a sociedade limitada apenas em 1977. Portanto, quase 60 anos após o Brasil! E como era de se esperar, tendo em vista a tradição do mercado norte-americano, o fizeram com acerto, optando por conferir aos sócios ampla liberdade contratual para a organização interna dos assuntos societários, reservando à lei algumas poucas regras cogentes e a grande maioria de disposições supletivas. Não por acaso, a LLC se tornou um estrondoso sucesso, a ponto de superar a sociedade anônima como a principal opção do investidor para a estruturação de empreendimentos de pequeno porte nos EUA. Isto se deu, em grande medida, pelas vantagens tributárias da LLC, mas também porque o legislador teve a percepção de que deveria prestigiar o contrato social como principal fonte das regras societárias. Ou seja, adotou postura 
diametralmente oposta à do Código Civil brasileiro de 2002, filiando-se ao modelo de tratamento legislativo que era anteriormente consagrado pelo Decreto n. 3.708/1919.

Assim, nos EUA, a existência de cotas preferenciais, com ou sem restrições ao direito de voto, é um assunto puramente contratual. Admite-se, inclusive, a completa supressão do direito de voto de algum cotista, à semelhança do que sucede com as ações preferenciais.

Esse exemplo comparativo serve para ilustrar que a postura adotada pelo Código Civil brasileiro de 2002, em relação ao tema, foi de todo infeliz. De qualquer modo, não se pode desprezar a legislação vigente. Sendo assim, o que este estudo procurou demonstrar é o equívoco dos órgãos de registro empresarial do país, consistente em proibir qualquer espécie de cota preferencial, com ou sem restrição do direito de voto, ante à inexistência de amparo legal para esse tipo de interpretação. Por outro lado, a proibição de cotas com restrição de voto quer se trate de deliberação imposta por lei ou apenas pelo contrato social - é justificável e admissível.

Essa não é, nem de longe, a solução ideal, haja vista o sucesso que a LLC vem alcançando no mercado norte-americano, baseado justamente no modelo oposto. Parece-nos, porém, que é a solução possível, diante da lei em vigor no Brasil.

\section{REFERÊNCIAS}

ABRÃO, Nelson. Sociedade por quotas de responsabilidade limitada. 5. ed. São Paulo: Revista dos Tribunais, 1995.

ADAMEK, Marcelo Vieira von. Abuso de Minoria em Direito Societário. São Paulo: Malheiros, 2014.

AMENDOLARA, Leslie. Os Direitos dos Minoritários na Sociedade Limitada. São Paulo: Quartier Latin, 2006.

ANGELICI, Carlo; FERRI, Giovanni. Manuale di Diritto Commerciale. 12. ed. Torino: Utet Giuridica, 2006.

AULETTA, Giuseppe; SALANITRO, Niccolò. Diritto Commerciale. Milano: Giuffrè, 2003.

BAGLEY, William D.; WHYNOTT, Philip P. The Limited Liability Company. Los Angeles: James Publishing, 1994.

BEBCHUK, Lucian Arye; COHEN, Alma. Firms' Decisions Where To Incorporate.Journal of Law and Economics. Chicago: University of Chicago Press. v. 46, n. 02, p. 383-425, Oct. 2003. 
BERLE JR., Adolf; MEANS, Gardiner C. The Modern Corporation and Private Property.7. ed. New Jersey: Transaction Publishers, 2005.

BORBA, José Edwaldo Tavares. Direito Societário. 9. ed. Rio de Janeiro: Renovar, 2004.

BORGES, João Eunápio. Curso de Direito Comercial Terrestre. Rio de Janeiro: Forense, 1959. v. 1.

BOTREL, Sérgio. Fusões \& Aquisições. 3. ed. São Paulo: Saraiva, 2014.

BRASIL. Bolsa de Valores, Mercadorias e Futuros - BM\&FBovespa. Regulamento do Novo Mercado. São Paulo: BM\&FBovespa. Disponível em:

<http://www.bmfbovespa.com.br/Pdf/RegulamentoNMercado.pdf>. Acesso em: 29 nov. 2015.

BRASIL. Congresso Nacional. Decreto $n^{\circ} 3.719$ de 15 de janeiro de 1919. Corrige enganos com que foi publicada a lei n. 3.674, de 7 de janeiro de 1919. In: Diário Oficial da União. Rio de Janeiro, RJ: 15 jan. 1919.

BRASIL. Congresso Nacional. Decreto-Lei n 2.627 de 26 de setembro de 1940. Dispõe sobre as sociedades por ações. Rio de Janeiro, RJ: 26 set. 1940. Disponível em: < http://www.planalto.gov.br/ccivil_03/decreto-lei/Del2627.htm>.

BRASIL. Congresso Nacional. Lei $\mathrm{n}^{\circ} 3.071$ de $1^{\circ}$ de janeiro de 1916. Código Civil. Diário Oficial da União. Rio de Janeiro, RJ: 01 jan. 1916.

BRASIL. Congresso Nacional. Lei $n^{\circ} 6.404$ de 15 de dezembro de 1976.Dispõe sobre as sociedades por ações. Diário Oficial da União. Brasília, DF: 15 dez. 1976.

BRASIL. Departamento de Registro Empresarial e Integração - DREI. Estatísticas. Brasília: DREI. Disponível em <http://drei.smpe.gov.br//assuntos/estatisticas/capa-editoria-b>. Acesso em: 28 nov. 2015.

BRASIL. Departamento de Registro Empresarial e Integração - DREI. Instrução Normativa n 10/2013 (Manual de Atos de Registro de Sociedade Limitada). Brasília: DREl. Disponível em <http://drei.smpe.gov.br/legislacao/instrucoes-normativas/titulo-menu/pasta-instrucoesnormativas-em-vigor-04/in102013anexo2-manual-de-registro-sociedade-limitada-08-092014.pdf>. Acesso em: 30 nov. 2015.

BRASIL. Departamento Nacional de Registro do Comércio - DNRC. Estatísticas. Brasília: DNRC. Disponível em <http://www.dnrc.gov.br/>. Acesso em: 28 nov. 2015.

BRASIL. Departamento Nacional de Registro do Comércio - DNRC. Instrução Normativa n $^{\circ}$ 98/2003 (Manual de Atos de Registro de Sociedade Limitada). Brasília: DNRC. Disponível em <http://drei.smpe.gov.br/legislacao/instrucoes-normativas/titulo-menu/pastainstrucoes-normativas-em-vigor-02-1/instrucao-normativa-no-98-de-23-de-dezembro-de-2003>. Acesso em: 30 nov. 2015.

BRASIL. Império. Lei $n^{\circ} 556$ de 25 de junho de 1850. Dispõe sobre o Código Comercial. Coleção de Leis do Brasil de 1850. Rio de Janeiro, RJ: 25 jun. 1850. 
BRASIL. Junta Comercial do Estado de São Paulo. Parecer n 137/1981. Boletim JUCESP.São Paulo: Diário Oficial do Estado de São Paulo, v. 91, n. 158, 1981.

BRASIL. República. Decreto ${ }^{\circ} 21.536$ de 15 de junho de 1932. Dispõe sobre o modo de constituição do capital das sociedades anônimas, permitindo que ele se constitua, em parte, por ações preferenciais de uma ou mais classes. Diário Oficial da União. Rio de Janeiro, RJ: 15 jun. 1932.

BRASIL. República. Decreto $n^{\circ} 434$ de 4 de julho de 1891. Consolida as disposições legislativas e regulamentares sobre as sociedades anonymas. Coleção de Leis do Brasil de 1891. Rio de Janeiro, RJ: 04 jul. 1891.

BULGARELLI, Waldírio. Manual das Sociedades Anônimas. 7. ed. São Paulo: Atlas, 1993. CAMPINHO, Sérgio. O Direito de empresa: À Luz do Novo Código Civil. 11. ed. Rio de Janeiro: Renovar, 2010.

COELHO, Fábio Ulhoa. O Futuro do Direito Comercial.São Paulo: Saraiva, 2011.

CONAWAY, Ann E. A Business Review of the Delaware Series: Good Business for the Informed. Widener Law School Research Paper Series. Wilmington: Widener Law School, n. 19, p. 01-58, Oct. 2008. Disponível em: <http: //papers.ssrn.com/sol3/papers.cfm?abstract_id=1097645>. Acesso em: 02 dez. 2015.

CORDEIRO, António Menezes. Direito das Sociedades Das Sociedades em Geral. 2. ed. Coimbra: Almedina, 2014. v. II.

DE LUCCA, Newton. Texto introdutório ao Livro II - Do Direito de Empresa. In: ALVIM, Arruda; ALVIM, Thereza (Coord.). Comentários ao Código Civil Brasileiro:Do Direito de Empresa. Rio de Janeiro: Forense, 2005. v. IX.

DINIZ, Gustavo Saad. A primeira década do Código Civil e alguns problemas para as organizações empresariais. Revista dos Tribunais. São Paulo: Revista dos Tribunais, v. 101, n. 917, p. 207222, mar. 2012.

FERREIRA, Waldemar Martins. Sociedades por Quotas. 5. ed. São Paulo: Monteiro Lobato, 1925.

FORGIONI, Paula Andrea. A Evolução do Direito Comercial Brasileiro: da mercancia ao mercado. São Paulo: Revista dos Tribunais, 2009.

GALIZZI, Gustavo Oliva; CAMARGO, Diogo Tressoldi. Investimento de Terceiro na Sociedade Limitada Familiar: Regulação do Poder de Controle. In: COELHO, Fábio Ulhoa; FÉRES, Marcelo Andrade (Coord.). Empresa Familiar: estudos jurídicos. São Paulo: Saraiva, 2014.

GUERREIRO, José Alexandre Tavares. Sociedade por Quotas - Quotas Preferenciais. Revista de Direito Mercantil, Industrial, Econômico e Financeiro. São Paulo: Malheiros, ano XXXIII, n. ${ }^{\circ} 94$, p. 28-34, abr./jun. 1994.

HAMILL, Susan Pace. The Origins Behind the Limited Liability Company. Ohio State Law Journal. Columbus: Ohio State University, v. 59, n. 05, p. 1459-1522, mar. 1998. 
HANSMANN, Henry; DAVIES, Paul; KRAAKMAN, Reinier R. et ai. The Anatomy of Corporate Law: A Comparative and Functional Approach. Oxford: Oxford University Press, 2004.

HANSMANN, Henry; DAVIES, Paul; KRAAKMAN, Reinier R. et al. The New Business Entities in Evolutionary Perspective. University of Illinois Law Review. Urbana-Champaign: University of Illinois College of Law. v. 05, n. 01, p. 05-14, Feb. 2005.

KLEIN, William A.; COFFEE, John C.; PARTNOY JR, Frank. Business Organization and Finance: Legal and Economic Principles. 11. ed. New York: Foundation Press, 2010.

KOBAYASHI, Bruce H.; RIBSTEIN, Larry E. Delaware for Small Fry: Jurisdictional Competition for Limited Liability Companies. University of Illinois Law Review. Urbana-Champaign: University of Illinois College of Law. v. 2011, n. 01, p. 91-144, 2011.

LAMY FILHO, Alfredo; BULHÕES PEDREIRA, José Luiz. Introdução. In: LAMY FILHO, Alfredo; BULHÕES PEDREIRA, José Luiz (Coord.). Direito das Companhias. Rio de Janeiro: Forense, 2009. V. I.

LOBO, Jorge. Sociedades Limitadas. Rio de Janeiro: Forense, 2004. v. 1.

LUCENA, José Waldecy. Das Sociedades Limitadas. 6. ed. Rio de Janeiro: Renovar, 2005.

MOTA, Fernando de Andrade. Restrição do Direito de Voto na Sociedade Limitada. Revista de Direito Mercantil, Industrial, Econômico e Financeiro. São Paulo: Malheiros, ano LII, n. 164/165, p. 124-137, jan./ago. 2013.

PARENTONI, Leonardo; GONTIJO, Bruno Miranda. Competência Legislativa em Direito Societário: Sistemas Brasileiro, Norte-Americano e Comunitário Europeu. No prelo.

PARGENDLER, Mariana. Cinco mitos sobre a história das sociedades anônimas no Brasil. In: KUYVEN, Luiz Fernando Martins (Coord.). Temas Essenciais de Direito Empresarial:Estudos em Homenagem a Modesto Carvalhosa. São Paulo: Saraiva, 2012.

PASSOS, Edilenice; LIMA, João Alberto de Oliveira. Memória Legislativa do Código Civil: Tramitação no Senado Federal. Brasília: Senado Federal, 2012. v. 3. Disponível em: <http://www.senado.gov.br/publicacoes/mlcc/pdf/mlcc_v3_ed1.pdf>. Acesso em: 10 ago. 2015.

PATROCíNIO, Daniel Moreira do. Sociedade Limitada: Comentários. São Paulo: Juarez de Oliveira, 2008.

REQUIÃO, Rubens. Curso de Direito Comercial. 25. ed. São Paulo: Saraiva, 2003. v. 1.

RIBEIRO, Renato Ventura. Direito de Voto nas Sociedades Anônimas. São Paulo: Quartier Latin, 2009. 
RIBSTEIN, Larry E. An Analysis of the Revised Uniform Limited Liability Company Act. Virginia Law \& Business Review. Charlottesville: University of Virginia. v. 03, n. 01, p. 36-80, Spring. 2008.

ROE, Mark J. Strong Managers, Weak Owners: The Political Roots of American Corporate Finance. Princeton: Princeton University Press, 1994.

ROMANO, Roberta. The Genius of American Corporate Law. Washington: AEI Press, 1993.

RUTLEDGE, Thomas E. Allocating Voting and Economic Rights in LLC: An Invitation to Confusion. Journal of Passthrough Entities. New York: CCH Incorporated. v. 16, n. 06, p. 69-75, Nov./Dec. 2013.

RUTLEDGE, Thomas E. Let's Stop Describing LLCs as "Hybrids". Journal of Passthrough Entities. New York: CCH Incorporated. v. 33, n. 01, p. 33-38, Sep./Oct. 2014.

SIMIONATO, Frederico A. Monte. Tratado de Direito Societário. Rio de Janeiro: Forense, 2009. v. I.

TOKARS, Fábio Leandro. Sociedades Limitadas. São Paulo: LTr, 2007.

TOMAZZETE, Marlon. Curso de Direito Empresarial:Teoria Geral e Direito Societário. 5. ed. São Paulo: Atlas, 2013. v. 1.

UNITED STATES OF AMERICA. Delaware Department of State: Division of Corporations.

Disponível em: <http://www.corp.delaware.gov/aboutagency.shtml>. Acesso em: 20 abr. 2015.

UNITED STATES OF AMERICA. Delaware Department of State. Delaware Limited Liability Company Act.Disponível em: <http://delcode.delaware.gov/title6/c018/>. Acesso em: 02 dez. 2015.

UNITED STATES OF AMERICA. Limited Liability Company Center. Disponível em: <http://www.limitedliabilitycompanycenter.com/>. Acesso em: 02 dez. 2015.

UNITED STATES OF AMERICA. Uniform Law Commission. Revised Uniform Limited Liability Company Act - RULLCA.Disponível em: <http: //www.uniformlaws.org/>. Acesso em: 02 dez. 2015.

WALD, Arnoldo. Do Direito de Empresa. In: TEIXEIRA, Sálvio de Figueiredo (Coord.). Comentários ao Novo Código Civil. Rio de Janeiro: Forense, 2005. v. 14.

WALKER, David S. A Consideration of an LLC for a 501(C)(3) Nonprofit Organization. Drake University Law School Research Paper Series. Des Moines: Drake University, n. 24, p. 626-677, Oct. 2012. Disponível em: <http://papers.ssrn.com/sol3/papers.cfm?abstract_id=2158907>. Acesso em: 02 dez. 2015.

Recebido em: 20/06/2016 / Aprovado em: 04/07/2016 